\title{
Oxidation photochemistry in the Southern Atlantic boundary layer: unexpected deviations of photochemical steady state
}

\author{
Z. Hosaynali Beygi ${ }^{1}$, H. Fischer ${ }^{1}$, H. D. Harder ${ }^{1}$, M. Martinez ${ }^{1}$, R. Sander ${ }^{1}$, J. Williams ${ }^{1}$, D. M. Brookes ${ }^{2}$, \\ P. S. Monks ${ }^{2}$, and J. Lelieveld ${ }^{1,3}$ \\ ${ }^{1}$ Max Planck Institute for Chemistry, Department of Atmospheric Chemistry, Mainz, Germany \\ ${ }^{2}$ University of Leicester, Department of Chemistry, Atmospheric Chemistry Group, UK \\ ${ }^{3}$ The Cyprus Institute, Nicosia, Cyprus
}

Received: 22 December 2010 - Published in Atmos. Chem. Phys. Discuss.: 2 March 2011

Revised: 11 August 2011 - Accepted: 15 August 2011 - Published: 22 August 2011

\begin{abstract}
Ozone $\left(\mathrm{O}_{3}\right)$ is a photochemical oxidant, an air pollutant and a greenhouse gas. As the main precursor of the hydroxyl radical $(\mathrm{OH})$ it strongly affects the oxidation power of the atmosphere. The remote marine boundary layer (MBL) is considered an important region in terms of chemi$\mathrm{cal} \mathrm{O}_{3}$ loss; however surface-based atmospheric observations are sparse and the photochemical processes are not well understood. To investigate the photochemistry under the clean background conditions of the Southern Atlantic Ocean, ship measurements of $\mathrm{NO}, \mathrm{NO}_{2}, \mathrm{O}_{3}, \mathrm{~J}_{\mathrm{NO}_{2}}, \mathrm{~J}\left(\mathrm{O}^{1} \mathrm{D}\right), \mathrm{HO}_{2}, \mathrm{OH}$, $\mathrm{RO}_{\mathrm{x}}$ and a range of meteorological parameters were carried out. The concentrations of $\mathrm{NO}$ and $\mathrm{NO}_{2}$ measured on board the French research vessel Marion-Dufresne $\left(28^{\circ} \mathrm{S}-57^{\circ} \mathrm{S}\right.$, $46^{\circ} \mathrm{W}-34^{\circ} \mathrm{E}$ ) in March 2007, are among the lowest yet observed.

The data is evaluated for consistency with photochemical steady state (PSS) conditions, and the calculations indicate substantial deviations from PSS $(\Phi>1)$. The deviations observed under low $\mathrm{NO}_{\mathrm{x}}$ conditions (5-25 pptv) demonstrate a remarkable upward tendency in the Leighton ratio (used to characterize PSS) with increasing $\mathrm{NO}_{\mathrm{x}}$ mixing ratio and $J_{\mathrm{NO}_{2}}$ intensity.

It is a paradigm in atmospheric chemistry that $\mathrm{OH}$ largely controls the oxidation efficiency of the atmosphere. However, evidence is growing that for unpolluted low- $\mathrm{NO}_{\mathrm{x}}$ $\left(\mathrm{NO}+\mathrm{NO}_{2}\right)$ conditions the atmospheric oxidant budget is poorly understood. Nevertheless, for the very cleanest conditions, typical for the remote marine boundary layer, good model agreement with measured $\mathrm{OH}$ and $\mathrm{HO}_{2}$ radicals has been interpreted as accurate understanding of baseline photo-
\end{abstract}

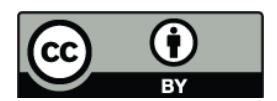

Correspondence to: Z. Hosaynali Beygi (zeinab.beygi@mpic.de) chemistry. Here we show that such agreement can be deceptive and that a yet unidentified oxidant is needed to explain the photochemical conditions observed at $40^{\circ}-60^{\circ} \mathrm{S}$ over the Atlantic Ocean.

\section{Introduction}

The remote MBL occupies about $25 \%$ of the Earth's surface and provides optimal conditions to study baseline photochemical processes (Monks et al., 1998; Penkett et al., 1997). Ozone plays a central role in atmospheric chemistry as the primary precursor of $\mathrm{OH}$ radicals through its photodissociation by solar ultraviolet radiation (Levy, 1971). In the troposphere, including the MBL, $\mathrm{O}_{3}$ is formed though the oxidation of NO into $\mathrm{NO}_{2}$ (Crutzen et al., 1994; Logan, 1981). The subsequent photodissociation of $\mathrm{NO}_{2}$ yields ground state oxygen, which combines with molecular oxygen:

$$
\begin{aligned}
& \mathrm{NO}_{2}+h v \rightarrow \mathrm{NO}+\mathrm{O} \quad(\lambda<424 \mathrm{~nm}) \\
& \mathrm{O}+\mathrm{O}_{2}(+\mathrm{M}) \rightarrow \mathrm{O}_{3}(+\mathrm{M})
\end{aligned}
$$

( $\mathrm{M}$ is an air molecule that removes excess energy)

In turn, ozone can regenerate the $\mathrm{NO}_{2}$, which together with Reactions (R1) and (R2) constitutes a null-cycle:

$\mathrm{NO}+\mathrm{O}_{3} \rightarrow \mathrm{NO}_{2}+\mathrm{O}_{2}$

In conditions where NO-to- $\mathrm{NO}_{2}$ conversion is dominated by Reaction (R3), the overall process can be described by the "Leighton ratio" $\varphi$, representing photostationary steady state (PSS), typically achieved within minutes (Leighton, 1961):

Published by Copernicus Publications on behalf of the European Geosciences Union. 
$\varphi=J_{\mathrm{NO}_{2}}\left[\mathrm{NO}_{2}\right] / k_{3}\left[\mathrm{O}_{3}\right][\mathrm{NO}]$

$J_{\mathrm{NO}_{2}}$ is the photodissociation frequency of $\mathrm{NO}_{2}$ and $k_{3}$ the rate coefficient of Reaction (R3). In the polluted high- $\mathrm{NO}_{\mathrm{x}}$ atmosphere $\varphi$ is unity (Carpenter et al., 1998; Parrish et al., 1986; Thornton et al., 2002; Yang et al., 2004). In moderately polluted environments radical reactions play a proportionally larger role in the conversion of $\mathrm{NO}$ to $\mathrm{NO}_{2}$ and $\varphi$ is typically > 1 (Hauglustaine et al., 1999; Mannschreck et al., 2004; Ridley et al., 1992; Volz-Thomas et al., 2003). In this case the reactions of peroxy radicals $\mathrm{HO}_{2}$ and $\mathrm{RO}_{2}$ with $\mathrm{NO}$ compete with Reaction (R3) (R represents an alkyl group, in the clean marine atmosphere mostly $\mathrm{CH}_{3} \mathrm{O}_{2}$ from $\mathrm{CH}_{4}$ oxidation) (Crutzen et al., 1994).

In fact by only considering Eq. (1) we are disregarding additional reactions which are expected to be important at low $\mathrm{NO}_{\mathrm{x}}$, i.e. that of $\mathrm{NO}$ with $\mathrm{HO}_{2}$ and $\mathrm{RO}_{2}$. Thus we need to expand the denominator of Eq. (1) with the following reactions to account for the $\mathrm{NO}_{2}$ source terms:

$$
\begin{aligned}
& \mathrm{HO}_{2}+\mathrm{NO} \rightarrow \mathrm{NO}_{2}+\mathrm{OH} \\
& \mathrm{RO}_{2}+\mathrm{NO} \rightarrow \mathrm{NO}_{2}+\mathrm{RO}
\end{aligned}
$$

By rearranging in order to calculate the $\mathrm{NO}_{2}$ concentration at PSS we obtain:

$\left[\mathrm{NO}_{2}\right]_{\text {calculated }}=\left(\mathrm{k}_{3}\left[\mathrm{O}_{3}\right]+\mathrm{k}_{4}\left[\mathrm{HO}_{2}\right]+\mathrm{k}_{5}\left[\mathrm{RO}_{2}\right]\right)[\mathrm{NO}] / \mathrm{J}_{\mathrm{NO}_{2}}$

Several researchers have actually used the measured deviation from $\varphi=1$ to estimate the concentration of peroxy radicals (Cantrell et al., 1997; Hauglustaine et al., 1999; Parrish et al., 1986; Ridley et al., 1992; Thornton et al., 2002). There is a general disagreement among the theoretically calculated $\mathrm{RO}_{\mathrm{x}}$ concentrations and the observed and model calculated $\mathrm{RO}_{\mathrm{x}}$. This is also the case in this study as discussed below.

One cause for such disagreement could be an unknown or non-quantified oxidation pathway which can result in the additional oxidation of $\mathrm{NO}$ to $\mathrm{NO}_{2}$. Since it is unaccounted for in the Leighton ratio this leads to a significant overestimation of the theoretically calculated $\mathrm{RO}_{\mathrm{x}}$ compared to measured or model calculated $\mathrm{RO}_{\mathrm{x}}$. One additional pathway leading to deviations of $\varphi=1$, relevant for the MBL, is the reaction of NO with halogen monoxides (XO) (Carpenter et al., 1998; Read et al., 2008; Yang et al., 2004). XO (ClO, BrO or IO) can convert $\mathrm{NO}$ to $\mathrm{NO}_{2}$ via the reaction:

$\mathrm{XO}+\mathrm{NO} \rightarrow \mathrm{NO}_{2}+\mathrm{X}$.

Halogen oxides have been observed in remote marine regions (Yang et al., 2004) and possible XO contribution to the PSS of $\mathrm{NO}_{\mathrm{x}}$ and $\mathrm{O}_{3}$ is discussed in more detail below.

Deviations also occur when loss processes for $\mathrm{O}_{3}$ other than Reaction (3) become significant, so that $\mathrm{O}_{3}$ is no longer in steady state. The additional loss processes can be $\mathrm{O}_{3}$ photolysis, reactions of $\mathrm{O}_{3}$ with $\mathrm{NO}_{2}$, alkenes and radicals. At sunrise and sunset deviations are expected from unity due to small $J_{\mathrm{NO}_{2}}$ values, therefore steady state assumptions are not valid.

If the reaction time is not sufficient after perturbations in concentration of gases in the air mass e.g. due to source pollution, then PSS assumption is not valid. The decomposition of reservoir species such as Peroxy Acetyl Nitrate (PAN) as additional $\mathrm{NO}_{2}$ sources can also result in deviations from PSS. Reaction rates in the Leighton equation are also important for PSS calculations. The calculated ratios are significantly influenced by the uncertainties in the reaction rates of $k_{1}, k_{2}$ and $k_{3}$. Uncertainties in the measured values of $J_{\mathrm{NO}_{2}}, \mathrm{O}_{3}, \mathrm{NO}, \mathrm{NO}_{2}$ and $\mathrm{RO}_{\mathrm{x}}$ are another important factor. It is vitally important to carry out accurate, precise and simultaneous measurements of the mentioned species in order to better understand the causes for deviations.

Here we present evidence that, indeed, PSS photochemistry is well characterized in polluted conditions, including the MBL. But in the low- $\mathrm{NO}_{\mathrm{x}}$ conditions encountered during a ship cruise, sailing between the southern tips of South America and South Africa in the austral summer of 2007, we observed major deviations in $\varphi$ that cannot be reconciled with the prevalent theory, indicating a major gap in our understanding of baseline atmospheric photochemistry.

\section{Experimental}

\subsection{Cruise MD160}

The Marion Dufresne cruise, referred to as MD160, took place during the late austral summer, from 1 March 2007 in Punta Arenas, Chile $\left(70.85^{\circ} \mathrm{W}, 53.12^{\circ} \mathrm{S}\right)$, to 23 March 2007 in La Réunion Island $\left(55.36^{\circ} \mathrm{E}, 21.06^{\circ} \mathrm{S}\right)$. The cruise was part of the OOMPH project (Ocean Organics Modifying Particles in both hemispheres, see: www.atmosphere.mpg.de/ enid/oomph). The ship crossed the southern Atlantic Ocean from west to east between approximately $60^{\circ} \mathrm{S}$ to $20^{\circ} \mathrm{S}$ (Fig. 1). In this region of the globe strong westerlies prevail and severe weather and sea conditions are common, as indicated by the terms "Roaring Forties" and "Furious Fifties".

During the first part of the campaign drifting icebergs from Antarctica were often encountered, associated with cold air from the Southern Ocean. During this period cloud cover was extensive with periods of rain and sometimes snow. In contrast, during the second part of the campaign, cruising towards the African continent, both the temperature and radiation levels increased. The westerly wind speeds varied in strength from calm conditions up to $33 \mathrm{~m} \mathrm{~s}^{-1}$. Occasionally, gale force winds $\left(>17 \mathrm{~m} \mathrm{~s}^{-1}\right)$ occurred. The average wind speed was $10 \mathrm{~m} \mathrm{~s}^{-1}$ during the first half and $8 \mathrm{~m} \mathrm{~s}^{-1}$ in the second part of the campaign. Further details can be found in (Williams et al., 2010). 


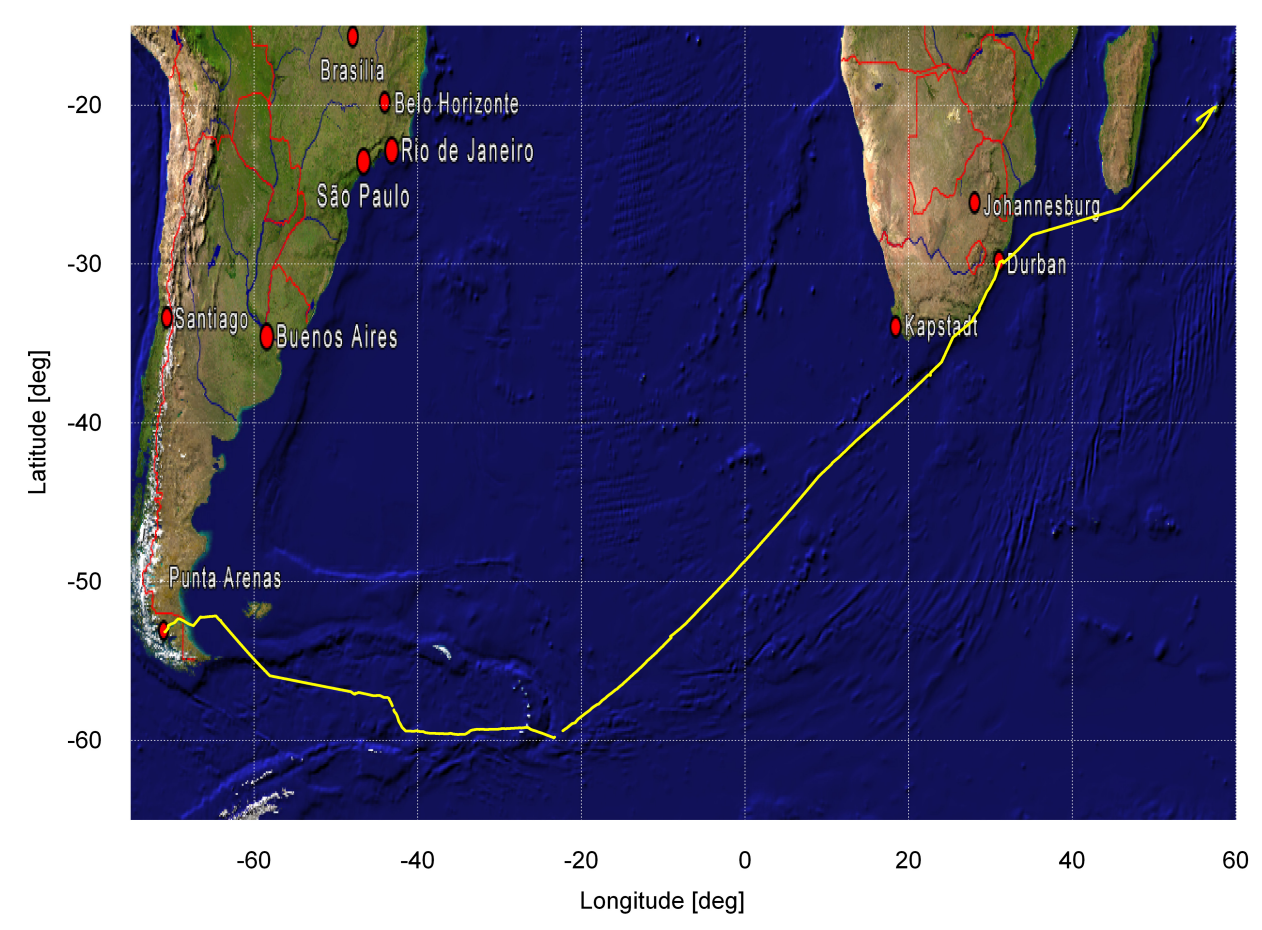

Fig. 1. The Marion Dufresne cruise track over the South Atlantic Ocean.

\subsection{Instrumental methods}

The most common meteorological measurements were performed, and in addition also balloon soundings, flux measurements and calculations of air flow dynamics and turbulence around the ship. In situ gas phase measurements included $\mathrm{O}_{3}, \mathrm{CO}, \mathrm{OH}, \mathrm{HO}_{2}, \mathrm{RO}_{\mathrm{x}}\left(\mathrm{RO}+\mathrm{RO}_{2}+\mathrm{HO}_{\mathrm{x}}\right)$, $\mathrm{NO}$ and $\mathrm{NO}_{2}$ concentrations as well as organic species like dimethyl sulphide (DMS), isoprene and halocarbons. Measurement of photodissociation frequencies were also performed on board the ship. The $\mathrm{NO}_{\mathrm{x}}$ and non-methane hydrocarbon concentrations measured were among the lowest reported to date. During pristine background conditions average ozone mixing ratios were $19.6( \pm 0.6) \mathrm{ppb}_{\mathrm{v}}$ and $\mathrm{NO}_{\mathrm{x}}$ mixing ratios $13.4( \pm 5.8) \mathrm{ppt}_{\mathrm{v}}( \pm 1 \sigma$ standard deviation). Note that the $\mathrm{NO}_{\mathrm{x}}$ data used in the following calculations exclude those that were below the total uncertainty $(2 \sigma)$ of the $\mathrm{NO}$ and $\mathrm{NO}_{2}$ measurements, 1.5 and 2.2 pptv, respectively, though the results and conclusions are robust and consistent by including all data. We focus on the period 1318 March 2007 during which a complete data set was obtained in air that spent at least 10 days over the Southern and South Atlantic Oceans and Antarctica without contact with air masses near the South American and African continents (Hosaynali Beygi, 2010).

\subsection{1 $\mathrm{NO}_{\mathrm{x}}$ and $\mathrm{O}_{3}$ measurements}

The instrument used to measure $\mathrm{NO}_{\mathrm{x}}$ and $\mathrm{O}_{3}$ is a high resolution and highly sensitive 3-channel chemiluminescence detector (CLD, ECO-Physics CLD 790 SR) which carries out simultaneous in situ measurements of $\mathrm{NO}_{2}, \mathrm{NO}$ and $\mathrm{O}_{3}$. The instrument was originally manufactured as a two channel system by ECO Physics Inc., Dürnten, Switzerland, and has been modified. One important modification has been the addition of a third channel for the measurement of $\mathrm{O}_{3}$ (Hosaynali Beygi, 2010).

To guarantee data quality, calibrations were performed during the campaign via the addition of a standard gas directly to the sample lines of the 3 channels. $\mathrm{NO}$ in $\mathrm{N}_{2}$ $(2.191 \pm 0.044$ ppmv, Air Liquide, Germany) was used as a calibration gas. The gas had a flow of $3.93 \mathrm{sccm}$ and was diluted to mixing ratios of approximately $2 \mathrm{ppb}_{\mathrm{v}}$ by synthetic air (SA). This standard was compared to a primary standard $(4.83 \pm 0.05$ ppmv, NIST, USA) before and after the campaign. The $\mathrm{NO}$ and $\mathrm{NO}_{2}$ channels were calibrated at least once per day.

Bottled synthetic air (Air Liquide, Germany), a zero air generator and a Purafil cartridge were employed in order to achieve optimum zeroing conditions for the CLD instrument. The bottled synthetic air used had a purity of 5.0 (corresponding to $99.9990 \%$ ) and the air consisted of a mixture of $\mathrm{O}_{2}(20.5 \%)$ and $\mathrm{N}_{2}$ (the rest) produced by Air Liquide, Germany. 
Table 1. Average and standard deviation of zero gas measurements for NO.

\begin{tabular}{lll}
\hline Date & $\begin{array}{l}\text { Average "zero gas" } \\
\text { (pptv) }\end{array}$ & $\begin{array}{l}\text { STDEV “zero gas" } \\
(1 \sigma, \mathrm{pptv})\end{array}$ \\
\hline 13.03 .07 & 1 & 1.4 \\
14.03 .07 & 0.8 & 1.3 \\
15.03 .07 & 0.8 & 1.3 \\
\hline
\end{tabular}

Table 2. Observed night time NO during pristine background conditions.

\begin{tabular}{llll}
\hline Date & $\begin{array}{l}\text { Median night } \\
\text { time (pptv) }\end{array}$ & $\begin{array}{l}\text { Average night } \\
\text { time (pptv) }\end{array}$ & $\begin{array}{l}\text { STDEV night } \\
\text { time (pptv) }\end{array}$ \\
\hline 13.03 .07 & 0.12 & 0.12 & 1.31 \\
14.03 .07 & 0.18 & 0.18 & 1.32 \\
15.03 .07 & 0.84 & 1.01 & 1.67 \\
\hline
\end{tabular}

Since the synthetic air can potentially contain interfering species a zero air generator was used. The zero air generator (CAP 30, Headline Filters GmbH, Germany) consisted of $\mathrm{Pd}$ and Pt catalysts and operated at a temperature of $370^{\circ} \mathrm{C}$. It was primarily used to remove hydrocarbons, aerosols and fine dust from bottled air used for zeroing of the instrument. Prior to the campaign the effects of a different variety of $\mathrm{Pu}$ rafil compounds were tested on the quality of the zero air in the laboratory. To avoid Purafil dust contamination, filters were used to prevent contamination of the inlet line and reaction chambers by the Purafil cartridge. The average and standard deviation of zero gas measurements for the NO channel are presented in Table 1. The indicated values have been calculated using the original $2 \mathrm{~s}$ data.

The conditions under which the measurements were performed were ideal in terms of testing the zeroing of the instrument. Since measurements were made in a pristine region without direct anthropogenic source pollution, it may be assumed that night time values measured during these periods are based on the complete conversion of $\mathrm{NO}$ to $\mathrm{NO}_{2}$. Due to the lack of solar radiation the back-conversion of $\mathrm{NO}_{2}$ to NO does not take place and therefore in a remote location without local $\mathrm{NO}_{\mathrm{x}}$ sources the $\mathrm{NO}$ mixing ratio is expected to equal zero. The standard deviation of the measured night time values was compared to the standard deviation of the SA measurements. They were in very good agreement, which corroborates the high quality (purity) of the synthetic gas (Tables 1 and 2).

The background signal of the three channels was determined with SA measurements and corrected for in the data. The detection limit (DL) of the measured species in this study was determined based on the reproducibility of the SA mea-
Table 3. Average and standard deviation of zero gas measurements for $\mathrm{NO}_{2}$.

\begin{tabular}{lll}
\hline Date & $\begin{array}{l}\text { Average "zero gas" } \\
\text { (pptv) }\end{array}$ & $\begin{array}{l}\text { STDEV “zero gas" } \\
(1 \sigma, \mathrm{pptv})\end{array}$ \\
\hline 13.03 .07 & 10.1 & 1.7 \\
14.03 .07 & 9.7 & 1.6 \\
15.03 .07 & 11.4 & 1.4 \\
\hline
\end{tabular}

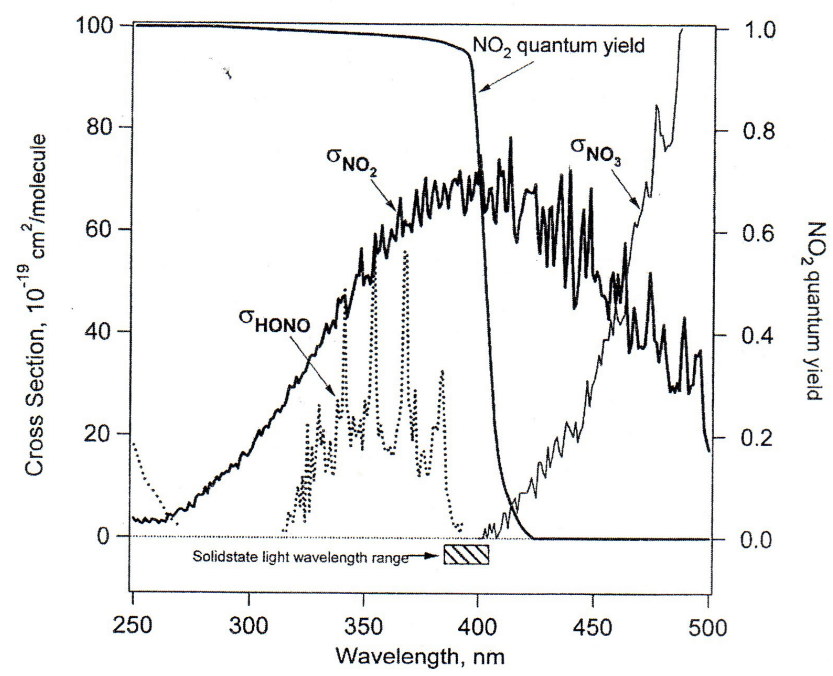

Fig. 2. BLC spectral information. The narrow wavelength range of the solid state LED's avoids effects of interfering species (source: BLC instrument manual, Droplet measurement technologies, USA).

surements carried out on a daily basis throughout the campaign. The DL, based on a $2 \sigma$ confidence level and $60 \mathrm{~s}$ integration time, is $0.47 \mathrm{pptv}, 0.51 \mathrm{pptv}$, and $18.2 \mathrm{pptv}$ for the $\mathrm{NO}, \mathrm{NO}_{2}$ and $\mathrm{O}_{3}$ channels, respectively.

$\mathrm{NO}_{2}$ was measured using a blue light converter which is a solid state photolytic converter (manufactured by Droplet Measurement Technologies, Colorado, USA). It uses an array of ultraviolet light emitting diodes (UV-LEDs) to photodissociate $\mathrm{NO}_{2}$ into $\mathrm{NO}$ at a wavelength of approximately $395 \mathrm{~nm}$. The LED's are mounted on a $\mathrm{BeO}$ (beryllium oxide) substrate and covered with a silicone overcoat. The sample gas passes the photolysis cell and the $\mathrm{NO}_{2}$ is converted to $\mathrm{NO}$ by the UV light from the LEDs. This type of BLC can have a conversion efficiency (CE) of $100 \%$ for $4 \mathrm{~s}$ residence time. The conversion efficiency of the BLC depends strongly on the residence time of the air sample in the cell. The residence time is a function of both cell flow and cell pressure. Lower pressure levels result in shorter residence times within the BLC and as a result lead to a decrease in the CE. Therefore, the $\mathrm{CE}$ of the BLC is highest at sea level pressure (which 
was the case during the campaign). The $\mathrm{CE}$ is also affected by the flow rate. High flow rates result in shorter residence times within the BLC and consequently lead to a lower CE. The residence time within the BLC was $1 \mathrm{~s}$.

High specificity is achieved by the narrow spectral output of the LEDs. The peak absorption cross section for $\mathrm{NO}_{2}$ is at $390-400 \mathrm{~nm}$, i.e. the wavelength range of the LEDs. This precludes the conversion of potential interfering species such as $\mathrm{HONO}, \mathrm{NO}_{3}$ and PAN (Fig. 2). This is discussed in more detail in Sect. 3.3.

The efficiency of the converter has been determined by gas phase titration (GPT) of $\mathrm{NO}$ with $\mathrm{O}_{3}$, before and during the campaign using a commercial instrument (ANSYCO GmbH, Karlsruhe, Germany). The calibration technique is based on the rapid gas phase reaction between $\mathrm{NO}$ and $\mathrm{O}_{3}$ to produce stoichiometric quantities of $\mathrm{NO}_{2}$. For this purpose both synthetic air and NO calibration gas were used. The quantitative knowledge of this reaction is such that when the NO concentration is known, the concentration of $\mathrm{NO}_{2}$ can be determined. $\mathrm{O}_{3}$ is added to $\mathrm{NO}$ in a dynamic calibration system, and the NO channel of the CL detector is used as an indicator of changes in NO concentration. A UV lamp is located inside the GPT instrument to generate $\mathrm{O}_{3}$. Upon addition of $\mathrm{O}_{3}$, the decrease of NO concentration observed in the calibrated NO channel is equivalent to the concentration of $\mathrm{NO}_{2}$ produced. From these values the CE of the BLC can be estimated.

As mentioned above, standard GPT, calibrations and zeroing of the instrument were carried out which are considered adequate to calculate the uncertainty and conversion efficiency. The efficiency of the BLC did not change significantly through the course of the campaign. The conversion efficiency during the period of study was $59 \%$ with an uncertainty of $\pm 1.8 \%$. The average and standard deviation of zero gas measurements for the $\mathrm{NO}_{2}$ channel are presented in Table 3. There is $\sim 10 \mathrm{pptv}$ offset during zeroing of the instrument. This offset was not seen once the blue light converter (BLC) was switched off. To correct for this the offset has been subtracted from the measurements; therefore, $\mathrm{NO}_{2}$ values after correction are approximately $10 \mathrm{pptv}$ lower than the measured signal.

The $\mathrm{O}_{3}$ channel was calibrated using a commercial $\mathrm{O}_{3}$ calibrator, (model TE49C, Thermo instruments GmbH, Germany) several times during the campaign. The only gas required for this measurement is SA which is fed directly into the $\mathrm{O}_{3}$ calibrator. Subsequently, $\mathrm{O}_{3}$ is produced by the $\mathrm{O}_{3}$ calibrator based on the specified set points e.g. $0 \mathrm{ppb}_{\mathrm{v}}$, $10 \mathrm{ppb}_{\mathrm{v}}, 20 \mathrm{ppb}_{\mathrm{v}} \ldots 100 \mathrm{ppb}_{\mathrm{v}}$, etc. The value measured by the CLD is read and compared to the actual set point value of the $\mathrm{O}_{3}$ calibrator.

The precision of the $\mathrm{NO}, \mathrm{NO}_{2}$ and $\mathrm{O}_{3}$ channels deduced from the sum of the DL and the reproducibility of the infield calibrations was $0.47 \mathrm{pptv}+2.68 \%$ (of total reading) for $\mathrm{NO}, 0.51 \mathrm{pptv}+2.68 \%$ for $\mathrm{NO}_{2}$ and $0.02 \mathrm{ppb}_{\mathrm{v}}+1 \%$ for $\mathrm{O}_{3}$, based on a confidence level of $2 \sigma$ and $60 \mathrm{~s}$ integration time.
The accuracy is calculated based on the total sum of the accuracy of the calibration standards used and also the uncertainty due to the offset corrections. The accuracy for the $\mathrm{NO}_{2}$ channel additionally contains the uncertainties in the conversion efficiency of the BLC. The accuracy is $1.4 \mathrm{pptv}+2 \%$ for the NO channel, $1.5 \mathrm{pptv}+2 \%$ for the $\mathrm{NO}_{2}$ channel and $0.5 \mathrm{ppb}_{\mathrm{v}}$ for the $\mathrm{O}_{3}$ channel.

The total uncertainty of the mixing ratio of a species can be determined by using the error propagation equation

$(\Delta \mathrm{C})^{2}=\left(\frac{\partial \mathrm{C}}{\partial \mathrm{E}_{1}} \Delta \mathrm{E}_{1}\right)^{2}+\left(\frac{\partial \mathrm{C}}{\partial \mathrm{E}_{2}} \Delta \mathrm{E}_{2}\right)^{2}+\left(\frac{\partial C}{\partial \mathrm{E}_{3}} \Delta \mathrm{E}_{3}\right)^{2}+\ldots$

$E_{\mathrm{X}}$ represents the different parameters with their uncertainties $\left(\Delta \mathrm{E}_{x}\right)$. Hence the total uncertainty based on the calculations of precision and accuracy is $1.5 \mathrm{pptv}+3.3 \%$ (of total reading) for the $\mathrm{NO}$ channel, $2.2 \mathrm{pptv}+5.3 \%$ for the $\mathrm{NO}_{2}$ channel and $0.5 \mathrm{pptv}+1 \%$ for the $\mathrm{O}_{3}$ channel.

The CLD instrument was setup inside a container which was located on the deck of the ship (Fig. 3). Air was sampled through a Teflon inlet line which was mounted on top of the atmospheric mast $10 \mathrm{~m}$ above the foredeck and approximately $20-25 \mathrm{~m}$ above the sea surface. From there an inlet line was installed to the container. The Teflon inlet line was placed inside black tubing in order to prevent photochemistry taking place in the inlet line. The total length of the inlet line was $17.1 \mathrm{~m}$ and consisted of $1 / 2^{\prime \prime}$ Teflon tubing (outer diameter). The last meter of the inlet line consisted of $1 / 4^{\prime \prime}$ Teflon tubing.

During the campaign the membrane pump maintained a flow of 19.2 SLM. The instrument preserved a total flow rate of 2.25 SLM by the use of a scroll pump. A peroxide analyzer (Aero-laser AL2021) shared the inlet line with the CLD instrument and applied a flow of 3 SLM. Therefore a total flow of 24.45 SLM was maintained in the inlet line. This corresponds to a retention time of $3.4 \mathrm{~s}$. The data was corrected for the residence time.

Inlet line calibrations and zeroing were carried out using a commercial GPT instrument. The standard GPT procedure is followed once in front of the inlet line and subsequently without the inlet line, directly connected to the instrument. Through a series of steps and comparison of the measured values in the two modes the amount of NO lost in the line can be estimated. For the MD160 campaign it is estimated that NO loss due to residence in the inlet line is less than $2 \%$. Note that zero gas calibrations with and without the inlet line rule out potential memory effects. There were also concerns regarding the inlet perturbations on $\mathrm{NO}_{2}$ e.g. PAN decomposition. The amount of $\mathrm{NO}_{2}$ produced in the inlet line through the reaction of $\mathrm{NO}$ with $\mathrm{O}_{3}$ was calculated for different periods of the study. It was found that the contribution due to this reaction was of the order of $1 \%$ or less of the total $\mathrm{NO}_{2}$ mixing ratio.

With regard to PAN decomposition, it is important to stress that PAN is relatively stable under the conditions the measurements were carried out, due to the low temperatures, 


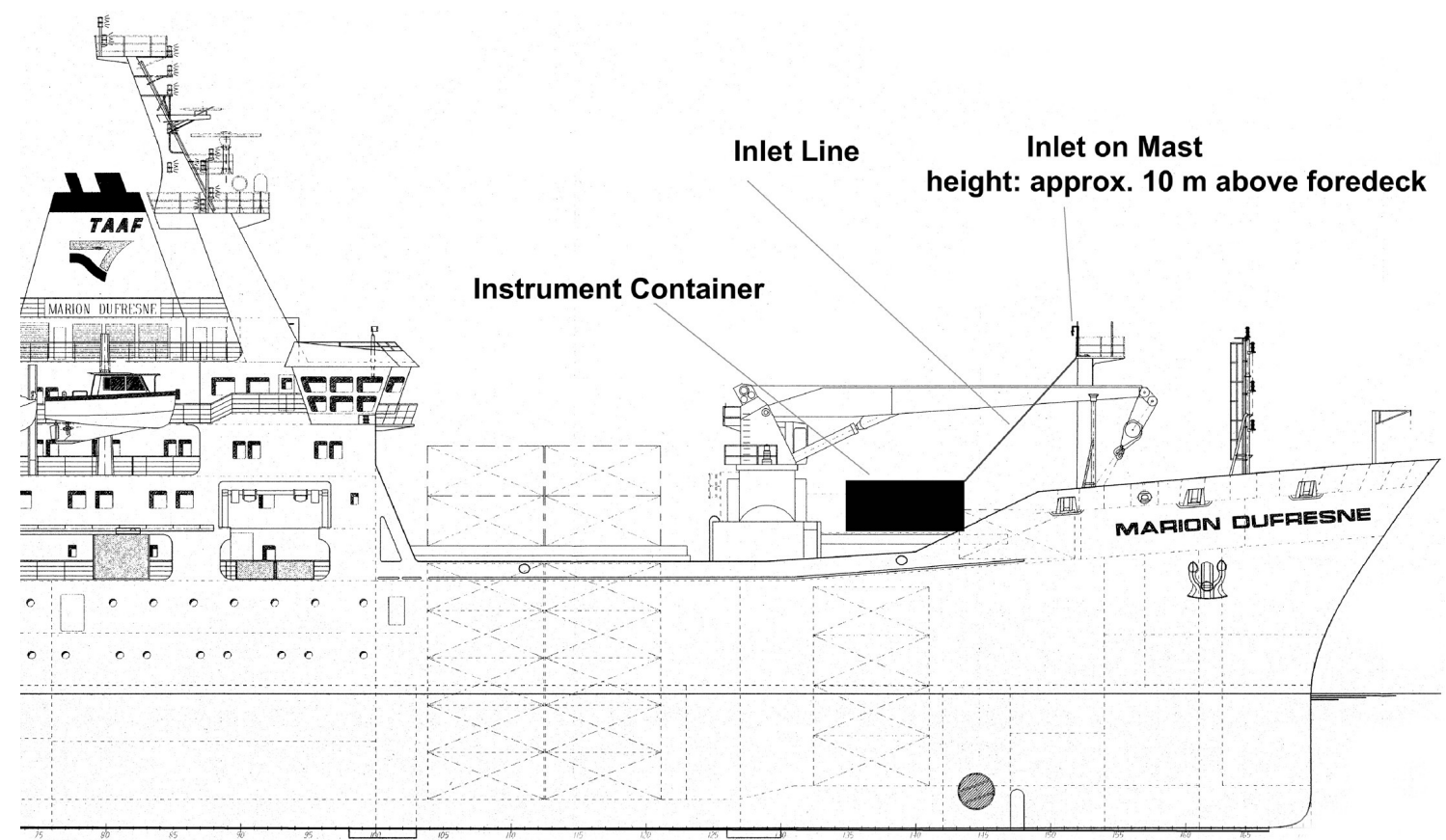

Fig. 3. Schematic of the Marion Dufresne to illustrate the position of the instrument container (black box) relative to the atmospheric mast (Zorn et al., 2008).

which varied on average between $3{ }^{\circ} \mathrm{C}$ and $11^{\circ} \mathrm{C}$ from 13 to 15 March, respectively. We calculated that PAN under the measurement conditions has an average lifetime of more than 1 day (see Sect. 3.3). We also calculated that in order for PAN to produce $7 \mathrm{pptv}$ of additional $\mathrm{NO}_{2}$, via thermal decomposition very high concentrations of PAN would be needed, i.e. at least several hundred pptv, which was not observed during the campaign.

\subsubsection{Radical and $J_{\mathrm{NO}_{2}}$ measurements}

For the data analysis several parameters measured with other instruments were used. The most important details of the instruments are presented next.

$\mathrm{OH}$ and $\mathrm{HO}_{2}$ were measured with the HORUS instrument (HydrOxyl Radical measurement Unit based on fluorescence Spectroscopy), which uses laser-induced fluorescence (LIF) of the $\mathrm{OH}$ molecule, based on the fluorescent assay by gas expansion (FAGE) technique. A detailed description of the instrument is given in (Martinez et al., 2010). The time resolution for $\mathrm{OH}$ and $\mathrm{HO}_{2}$ detection is $10 \mathrm{~s}$. The precision for a $60 \mathrm{~s}$ integration time and a confidence level of $1 \sigma$ is $0.017 \mathrm{pptv}$ for $\mathrm{OH}$ and $0.1 \mathrm{pptv}$ for $\mathrm{HO}_{2}$. The accuracy is $\pm 35 \%$ for a confidence level of $2 \sigma$. The DL of the instrument is defined as the $2 \sigma$ precision, assuming it is limited by the background noise.

The photodissociation rate of $\mathrm{NO}_{2}, J_{\mathrm{NO}_{2}}$, was measured using two (up- and downward) $2 \pi$-steradian (sr) filter radiometers (Meteorologie Consult $\mathrm{GmbH}$, Germany), thus providing $4 \pi$-sr photodissociation rates. The instrument has a precision of $5 \%$ for $1 \mathrm{~s}$ data and an accuracy of $10 \%$. The basic design is adopted from the device described by (Junkermann et al., 1989). The principles of $J_{\mathrm{NO}_{2}}$ filter radiometry are explained by (Volz-Thomas et al., 1996). The radiometer is annually calibrated at the research centre FZ-Jülich. Long term calibrations show a small variation (below $2 \%, 1 \sigma$ ) during one year.

$\mathrm{RO}_{\mathrm{x}}$ was measured using a peroxy radical chemical amplifier (PERCA). The PERCA technique was introduced in the early 1980s (Cantrell et al., 1997) and has been widely used since then (Parker et al., 2009). The detector is calibrated by the addition of $\mathrm{NO}_{2}$ and the chain length is calibrated by the addition of known concentrations of $\mathrm{CH}_{3} \mathrm{O}_{2}$. During MD160 the instrument was placed on top of the atmospheric mast above the foredeck. The PERCA instrument is sensitive to humidity hence a water correction is applied to all data. One data point was obtained per minute, however due to calibrations actual measurements are available every other minute. The uncertainty in the PERCA measurements leads to an accuracy of $36 \%$.

The uncertainty and DL of the relevant instruments used in this work are summarized in Table 4. For each measurement the total uncertainty is determined by the highest of the two values (pptv or \%). 
Table 4. Total uncertainty of the instrumentation.

\begin{tabular}{llll}
\hline Parameter & Instrument & Total uncertainty & Detection limit \\
\hline $\mathrm{NO}$ & $\mathrm{CLD}$ & $\begin{array}{l}1.5 \mathrm{pptv}+3.3 \% \\
( \pm 2 \sigma-60 \mathrm{~s})\end{array}$ & $0.47 \mathrm{pptv}$ \\
\hline $\mathrm{NO}_{2}$ & CLD and BLC & $\begin{array}{l}2.2 \mathrm{pptv}+5.3 \% \\
( \pm 2 \sigma-60 \mathrm{~s})\end{array}$ & $0.51 \mathrm{pptv}$ \\
\hline $\mathrm{O}_{3}$ & $\mathrm{CLD}$ & $\begin{array}{l}0.5 \mathrm{ppb}+1 \% \\
( \pm 2 \sigma-60 \mathrm{~s})\end{array}$ & $18.2 \mathrm{pptv}$ \\
\hline$J_{\mathrm{NO}}$ & Filter radiometer & $11 \%(2 \sigma 1 \mathrm{~s})$ & $1.5 \times 10^{-6}(\mathrm{~s}-1)$ \\
\hline $\mathrm{HO}_{2}$ & LIF instrument & $\begin{array}{l}0.1 \mathrm{pptv}+35 \% \\
( \pm 2 \sigma-10 \mathrm{~s})\end{array}$ & $0.2 \mathrm{pptv}$ \\
\hline $\mathrm{OH}$ & LIF instrument & $\begin{array}{l}0.017 \mathrm{pptv}+35 \% \\
( \pm 2 \sigma-10 \mathrm{~s})\end{array}$ & $0.034 \mathrm{pptv}$ \\
\hline $\mathrm{RO}_{\mathrm{x}}$ & PERCA & $\begin{array}{l}10 \mathrm{pptv}+36 \% \\
( \pm 2 \sigma-60 \mathrm{~s})\end{array}$ & $10 \mathrm{pptv}$ \\
\hline
\end{tabular}

\section{Results and discussions}

\subsection{Back trajectory calculations and data filtering}

Meteorological data and the Lagrangian Analysis Tool (LAGRANTO) were used to calculate the 10-day back trajectories of the air masses (Wernli and Davies, 1997).

Every $3 \mathrm{~h}$ about 10 trajectories were started within a 30 min time interval at the ship position along the cruise track. The path of the trajectories was calculated using three-dimensional wind fields from the European Centre for Medium-Range Weather Forecasts (ECMWF). For the analysis, 6-h operational global analyses are complemented by intermediate 3-h forecasts interpolated onto a horizontal grid with a resolution of $1^{\circ}$ latitude/longitude. The horizontal resolution of the model is $25 \mathrm{~km}$ using 91 vertical levels. The computational time step for trajectory calculations is $30 \mathrm{~min}$.

The 10-day back-trajectories show that the air masses came from the Southern and South Atlantic Ocean until 21st March, and that they originated mostly in the free troposphere, subsiding to the boundary layer before the measurements. Considering the air mass origins over the Antarctic continent and the surrounding oceans, the likelihood of anthropogenic contamination is small.

Depending on the wind direction and speed, the ship exhaust can be a source of contamination. During some periods wind from the rear gave rise to local pollution, which could be easily identified in many of the trace gas measurements. To exclude these events, measurement data with exhaust contamination were removed. The optimum filtering process was selected after considering a range of techniques and criteria. For the data used in PSS calculations additional $J_{\mathrm{NO}_{2}}$ filtering and a filter based on the uncertainty of the channels were applied.

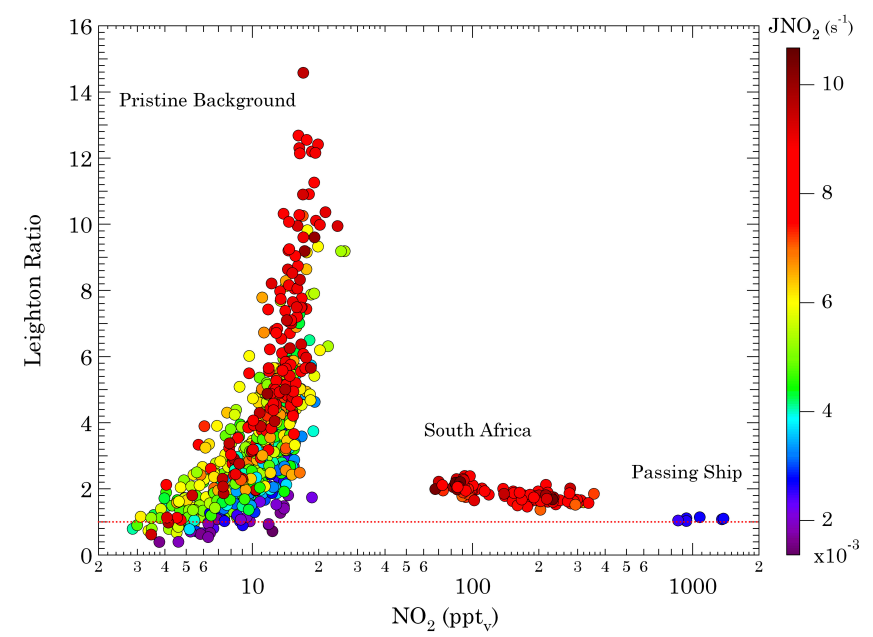

Fig. 4. Leighton ratio calculated from observations in the unpolluted MBL, in moderately polluted air near South Africa, and in the pollution plume of a passing ship. The color coding indicates the $\mathrm{NO}_{2}$ photodissociation frequency (which scales with light intensity). We estimate the $2 \sigma$ uncertainty in $\varphi$ at approximately $93 \%$, $71 \%, 63 \%$ and $11 \%$ for $\mathrm{NO}_{2}$ mixing ratios of 3, 5, 10 and $100 \mathrm{pptv}$, respectively.

The criteria for data exclusion included the wind direction relative to the direction of the ship, and signs of exhaust contamination in the CLD data. Pollution was observed when the wind came from $55^{\circ}$ and $275^{\circ}$ relative to the ship $\left(0^{\circ}\right.$ is the cruise direction). Further, a rigorous NO filter (based on $2 \mathrm{~s}$ measurements) was applied by removing outliers ( $3 \sigma$ relative to the $24 \mathrm{~h}$ average).

To carry out precise and accurate PSS calculations two additional filters were used. In the remote MBL the NO and $\mathrm{NO}_{2}$ concentrations are very low and close to the detection limit of the instrument. To ensure data quality a third filter was set up using the total uncertainty based on the calculations of precision and accuracy of the $\mathrm{NO}$ and $\mathrm{NO}_{2}$ channels. Any data point which was below the total uncertainty limit of the relevant channel was excluded. The $2 \sigma$ uncertainty for the $\mathrm{NO}$ and $\mathrm{NO}_{2}$ channels are 1.5 pptv and 2.2 pptv, respectively. To investigate the influence of this procedure, PSS calculations were carried out both with and without the uncertainty filter. The results of the two sets of calculations did not show significant differences.

Furthermore, PSS calculations are sensitive to uncertainties in $J_{\mathrm{NO}_{2}}$. At low $J_{\mathrm{NO}_{2}}$ values, e.g. during sunrise and sunset, deviations from PSS are expected. Therefore only data for $J_{\mathrm{NO}_{2}}>0.001 \mathrm{~s}^{-1}$ have been used.

\subsection{The Leighton ratio}

Figure 4 presents the Leighton ratios based on our observations in the unpolluted MBL. Considerable deviations from unity are evident, as predicted by previous studies 


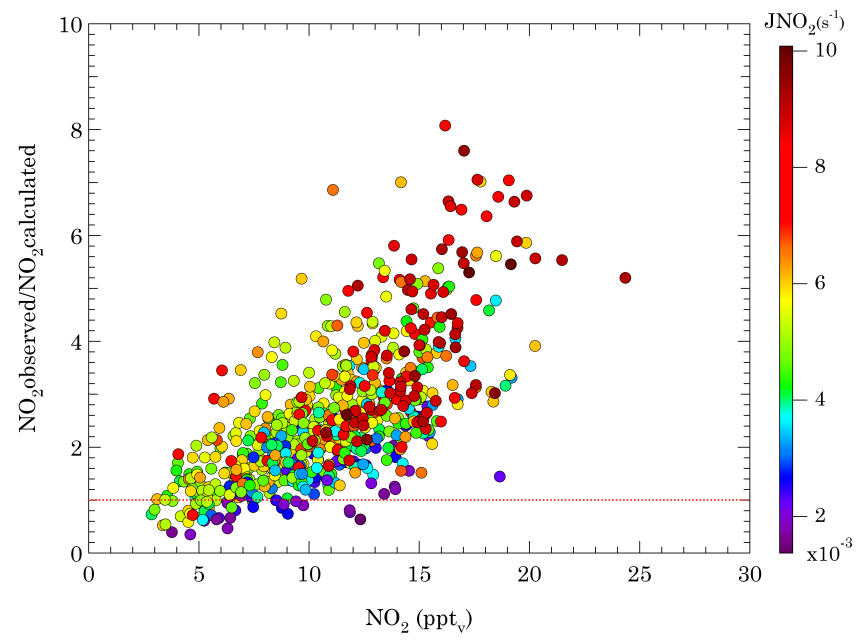

Fig. 5. The ratio of the observed and the PSS-calculated $\mathrm{NO}_{2}$ concentrations as a function of $\mathrm{NO}_{2}$ in the unpolluted MBL. The color coding indicates the $\mathrm{NO}_{2}$ photodissociation frequency.

(Hauglustaine et al., 1999; Mannschreck et al., 2004; Parrish et al., 1986; Volz-Thomas et al., 2003). However, noteworthy is the trend in $\varphi$ in the low- $\mathrm{NO}_{\mathrm{x}}$ regime, at variance with previous reports, and consistently observed during several days. If $\mathrm{RO}_{2}$ were a significant contributor to NO-to- $\mathrm{NO}_{2}$ conversion, it would have been expected that the maximum influence on $\varphi$ and deviations from unity occur at the lower end of the $\mathrm{NO}_{2}$ axis, i.e. around 3 pptv, and that the divergence decreases with increasing $\mathrm{NO}_{2}$. This tendency is actually observed in the moderately polluted air masses near South Africa (70-400 pptv $\mathrm{NO}_{2}$ ) and close agreement is found for an air mass that was polluted by a passing ship $\left(\sim 1 \mathrm{ppb}_{\mathrm{v}}\right)$ (Fig. 4).

The $J_{\mathrm{NO}_{2}}$ colour coding shows that the maximum deviations are not at the lowest $\mathrm{NO}_{2}$ and $J_{\mathrm{NO}_{2}}$ values, as expected from the established theory. In fact, for $\mathrm{NO}_{2}$ mixing ratios less than $10 \mathrm{pptv}$ and $J_{\mathrm{NO}_{2}}$ below $3-4 \times 10^{-3} \mathrm{~s}^{-1}$ we find that $\varphi \approx 1$ (within the uncertainty range). What is observed is that the maximum deviations in the unpolluted MBL occur at the highest $\mathrm{NO}_{2}$ mixing ratios (10-20 pptv) and the highest solar radiation intensities (proportional to $J_{\mathrm{NO}_{2}}$ ). This clearly indicates the importance of $\mathrm{NO}_{\mathrm{x}}$-mediated photochemistry. Unfortunately no data are available for the $20-60$ pptv $\mathrm{NO}_{2}$ (30-100 pptv $\mathrm{NO}_{\mathrm{x}}$ ) regime, and we anticipate that a reverse tendency to that for 3-20 pptv $\mathrm{NO}_{2}\left(5-30 \mathrm{pptv} \mathrm{NO}_{\mathrm{x}}\right.$ ) may occur and an increasing dominance of Reaction (R3).

Next we analyze to what degree $\varphi \neq 1$ conditions can be explained by conventional theory, in particular by considering measurement uncertainties, and then also by making some assumptions about parameters that were not directly observed. The uncertainty in $\varphi$ in the low- $\mathrm{NO}_{\mathrm{x}}$ regime is mainly related to the $\mathrm{NO}$ and $\mathrm{NO}_{2}$ measurement data.

For $\mathrm{NO}_{\mathrm{x}}$ mixing ratios in the pptv range the uncertainty resulting from the measurement of $\mathrm{NO}$ and $\mathrm{NO}_{2}$ dominates the

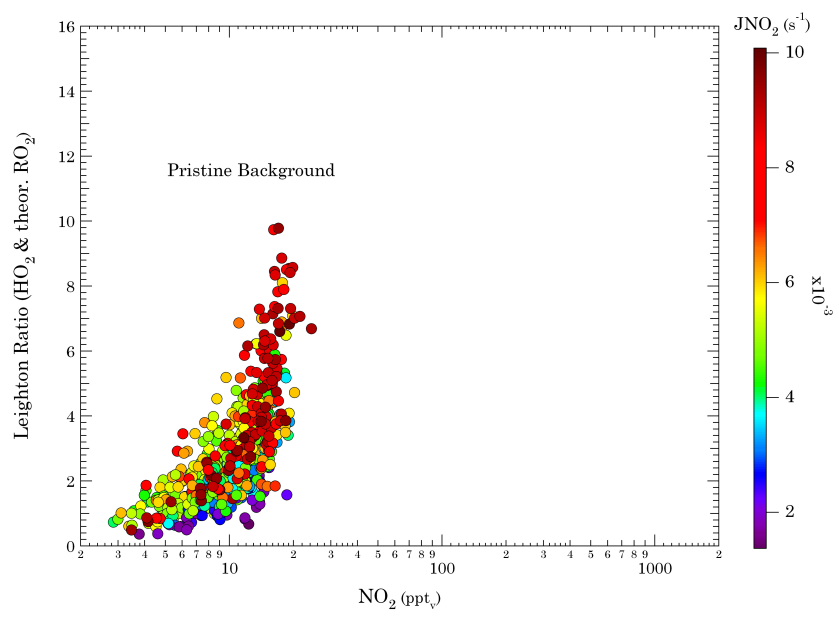

Fig. 6. Leighton ratio calculated using $\mathrm{HO}_{2}$ and theoretically assumed equal mixing ratio of $\mathrm{RO}_{2}$, as a function of $\mathrm{NO}_{2}$ mixing ratios. The colour bar indicates the $J_{\mathrm{NO}_{2}}$ intensity.

overall uncertainty, which increases with decreasing $\mathrm{NO}_{\mathrm{x}}$. Uncertainty estimates for PSS calculations have been reported to be up to $60 \%$ (Mannschreck et al., 2004). The overall uncertainty in the Leighton ratio $\varphi$ can be calculated through the sum of the individual uncertainties in each parameter using the following equation:

$\Delta \varphi=\sqrt{\varphi^{2} \cdot \sum\left(\frac{\Delta \mathrm{X}_{i}}{\mathrm{X}_{i}}\right)^{2}}$

$\mathrm{X}_{i}$ represents $J_{\mathrm{NO}_{2}}, \mathrm{NO}, \mathrm{NO}_{2}, \mathrm{HO}_{2}, \mathrm{O}_{3}$ and $\mathrm{RO}_{2}$, depending on which form of the PSS equation is used. For example, for Eq. (1) the uncertainty is calculated as:

$\Delta \varphi=\sqrt{\varphi^{2} \cdot\left(\left(\frac{\Delta \mathrm{JNO}_{2}}{\mathrm{JNO}_{2}}\right)^{2}+\left(\frac{\Delta \mathrm{NO}_{2}}{\mathrm{NO}_{2}}\right)^{2}+\left(\frac{\Delta k_{3}}{k_{3}}\right)^{2}+\left(\frac{\Delta \mathrm{O}_{3}}{\mathrm{O}_{3}}\right)^{2}+\left(\frac{\Delta \mathrm{NO}}{\mathrm{NO}}\right)^{2}\right)}$

With the addition of parameters to the equation, the uncertainties are added to the total uncertainty. The uncertainties can be expressed as a function of the $\mathrm{NO}_{2}$ mixing ratios. We estimate the $2 \sigma$ uncertainty in $\varphi$ at approximately $93 \%$, $71 \%, 63 \%$ and $11 \%$ for $\mathrm{NO}_{2}$ mixing ratios of $3,5,10$ and 100 pptv, respectively.

As mentioned before by only considering Eq. (1), we are disregarding additional reactions which are expected to be important at low $\mathrm{NO}_{\mathrm{x}}$, i.e. that of $\mathrm{NO}$ with $\mathrm{HO}_{2}$ and $\mathrm{RO}_{2}$. Therefore in a further step Eq. (2) was used in order to calculate the $\mathrm{NO}_{2}$ concentration at PSS. For this calculation we initially adopt $\left[\mathrm{HO}_{2}\right] \approx\left[\mathrm{RO}_{2}\right]$, a reasonable assumption for conditions in which hydrocarbon chemistry is dominated by methane (Crutzen et al., 1994), hence $\left[\mathrm{RO}_{2}\right] \approx\left[\mathrm{CH}_{3} \mathrm{O}_{2}\right]$ (to be evaluated below). Our analysis indicates a $2 \sigma$ uncertainty of $\left[\mathrm{NO}_{2}\right]_{\text {calculated }}$ based on Eq. 2) of about $108 \%, 89 \%$ and $82 \%$ at $\mathrm{NO}_{2}$ mixing ratios of 3,5 and 10 pptv, respectively.

If this expansion of Eq. (1) by including Reactions (R4) and (R5) would adequately account for NO-to- 


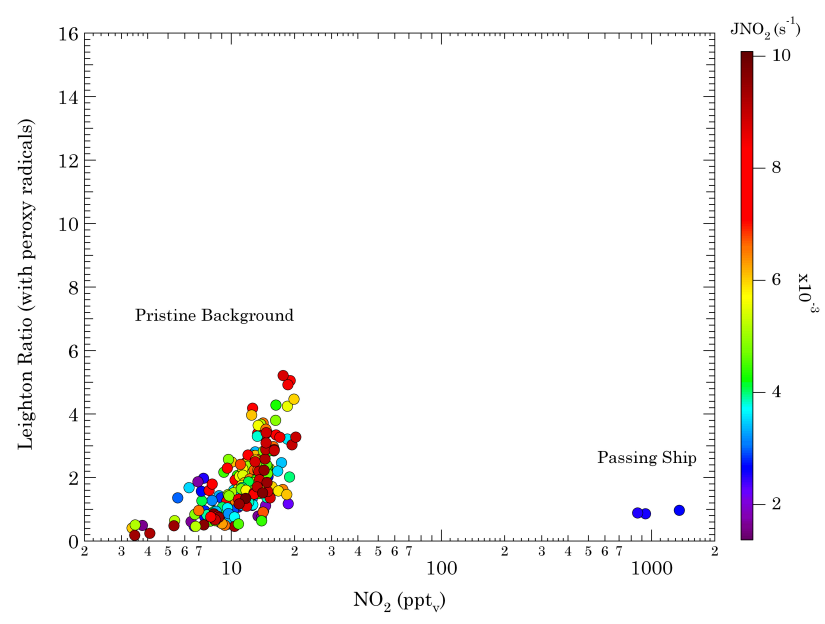

Fig. 7. Leighton ratio calculated using peroxy radical measurements from the PERCA instrument plotted as a function of $\mathrm{NO}_{2}$ mixing ratios. The colour bar indicates the $J_{\mathrm{NO}_{2}}$ intensity. Total uncertainties were calculated for the Leighton ratio, for several $\mathrm{NO}_{2}$ mixing ratios and are estimated to be $158 \%, 147 \%$ and $131 \%$ for $\mathrm{NO}_{2}$ mixing ratios of 3,5 and 10 pptv respectively.

$\mathrm{NO}_{2}$ conversions, both the adjusted $\varphi$ and the ratio $\left[\mathrm{NO}_{2}\right]_{\text {observed }} /\left[\mathrm{NO}_{2}\right]_{\text {calculated }}$ would be unity. Figure 5 shows that this is clearly not the case and the discrepancy ranges up to a factor of $\sim 7$. We also see that the largest deviations from unity occur in air masses with the highest $J_{\mathrm{NO}_{2}}$, whereas for low $J_{\mathrm{NO}_{2}}$ the ratio actually approximates unity. Again this is suggestive of a yet unaccounted photochemically driven oxidation process. Note that we have repeated these calculations for moderate- $\mathrm{NO}_{\mathrm{x}}$ and high- $\mathrm{NO}_{\mathrm{x}}$ conditions for which we obtain good agreement $\left(\left[\mathrm{NO}_{2}\right]_{\text {observed }} \approx\left[\mathrm{NO}_{2}\right]_{\text {calculated }}\right)$.

To investigate the effect of the peroxy radicals, the Leighton ratio was calculated in a second step using measured $\mathrm{HO}_{2}$ and theoretically assumed $\mathrm{RO}_{2}$. In this step it is assumed that $\mathrm{RO}_{2}$ concentrations were similar to those of $\mathrm{HO}_{2}$ based on model output and previous knowledge (as discussed below). The result of the analysis is demonstrated in Fig. 6. A decrease can be seen in the deviations from unity; however it is clear that the addition of peroxy radicals can not explain the deviations. In a third step to further investigate the effect of peroxy radicals on the Leighton ratio, calculations were carried out using peroxy radical mixing ratios obtained from the PERCA instrument instead of the theoretically assumed $\mathrm{RO}_{2}$ data. The results of this calculation are presented in Fig. 7. In this case a dramatic change is observed in the Leighton ratio of the pristine background conditions. That is, the maximum deviation seen in Fig. 7 is substantially lower compared with the values in Figs. 4 and 6.

The trend seen in the deviation from $\varphi=1$ as a function of $\mathrm{NO}_{2}$ and $J_{\mathrm{NO}_{2}}$ in the pristine background air masses does not change. In fact it is the same as for the classic Leighton ratio. This may again be an indication for an unknown photochem- ically driven oxidant that can convert $\mathrm{NO}$ to $\mathrm{NO}_{2}$ and therefore leads to significant deviation from unity in the Leighton ratio.

The values for the passing ship period have not changed and are similar to those plotted in Fig. 4. This is a strong confirmation of the relative insignificance of $\mathrm{RO}_{\mathrm{x}}$ reactions in high $\mathrm{NO}_{\mathrm{x}}$ regimes.

Total uncertainties were calculated for the Leighton ratio, for several $\mathrm{NO}_{2}$ mixing ratios and are estimated to be $158 \%$, $147 \%$ and $131 \%$ for $\mathrm{NO}_{2}$ mixing ratios of 3,5 and $10 \mathrm{pptv}$ respectively. The uncertainties are higher than in previous cases due to the additional uncertainties in the peroxy instrument.

It is remarkable that the addition of PERCA derived peroxy radical concentrations causes such a strong change in the Leighton ratio and can to a large degree compensate for the high $\mathrm{NO}_{2}$ concentrations measured by the CLD instrument. Figure 8 presents time series of observed $J_{\mathrm{NO}_{2}}$ and radical species in addition to $\mathrm{NO}_{\mathrm{x}}$ and $\mathrm{O}_{3}$. Maximum $\mathrm{OH}$ mixing ratios reach up to $\sim 0.3 \mathrm{pptv}, \mathrm{HO}_{2} \sim 17 \mathrm{pptv}$ and $\mathrm{RO}_{\mathrm{x}}$ $\sim 150$ pptv. As the mixing ratios of the highly reactive $\mathrm{OH}$ and $\mathrm{RO}$ are low it may be assumed that their contribution to $\mathrm{RO}_{\mathrm{x}}$ is minor. As a consequence maximum $\mathrm{RO}_{2}$ mixing ratios would exceed $100 \mathrm{pptv}$, clearly inconsistent with the above assumption that $\mathrm{RO}_{2} \approx \mathrm{HO}_{2}$.

This assumption can be tested with a chemical box model, constrained by our measurements, and with output of a global chemistry-transport model.

A photochemical steady-state box model was used to simulate the ambient $\mathrm{HO}_{\mathrm{x}}, \mathrm{OH}$ and $\mathrm{CH}_{3} \mathrm{O}_{2}$ concentrations $\left(\mathrm{RO}_{2} \approx \mathrm{CH}_{3} \mathrm{O}_{2}\right)$. The model was set up and constrained using data obtained on the MD 160 cruise. The parameters used to constrain the box model are: $\mathrm{H}_{2}, \mathrm{CH}_{4}, \mathrm{H}_{2} \mathrm{O}_{2}$, $\mathrm{CH}_{3} \mathrm{OOH}, \mathrm{O}_{3}, \mathrm{NO}, \mathrm{CO}$, latitude, longitude, pressure, air temperature, $\mathrm{H}_{2} \mathrm{O}, \mathrm{JO}^{1} \mathrm{D}, J_{\mathrm{NO}_{2}}$, and a number of photolysis rates based on radiation calculations using measured $J_{\mathrm{NO}_{2}}$ as input, $\mathrm{JCHOH}, \mathrm{JCOH}_{2}, \mathrm{JH}_{2} \mathrm{O}_{2}, \mathrm{JCH}_{3} \mathrm{OOH}$ and $\mathrm{JNO}_{3}$. Steady state concentrations of $\mathrm{OH}, \mathrm{HO}_{2}$ and $\mathrm{CH}_{3} \mathrm{O}_{2}$ were calculated according to the method of (Kubistin et al., 2010). A model data point was calculated whenever the complete set of relevant data was available within a $10 \mathrm{~s}$ time period.

Under steady state conditions the production and loss rates for the radical species balance:

$$
\frac{d[\mathrm{X}]}{d t} \approx 0=\mathrm{P}_{\mathrm{X}}-\mathrm{L}_{\mathrm{X}}
$$

where $P_{x}$ represents the total production and $L x$ the loss rate. By this approach the diurnal profiles of the radicals and their average concentrations could be reproduced well, as shown in Fig. 9. Figure 10 demonstrates that according to these calculations $\mathrm{HO}_{2}$ and $\mathrm{CH}_{3} \mathrm{O}_{2}$ concentrations are very similar. This is in line with the observed $\mathrm{CO} / \mathrm{CH}_{4}$ ratio, as expected according to the prevailing theory of atmospheric radical photochemistry, because the production of $\mathrm{HO}_{2}$ and 


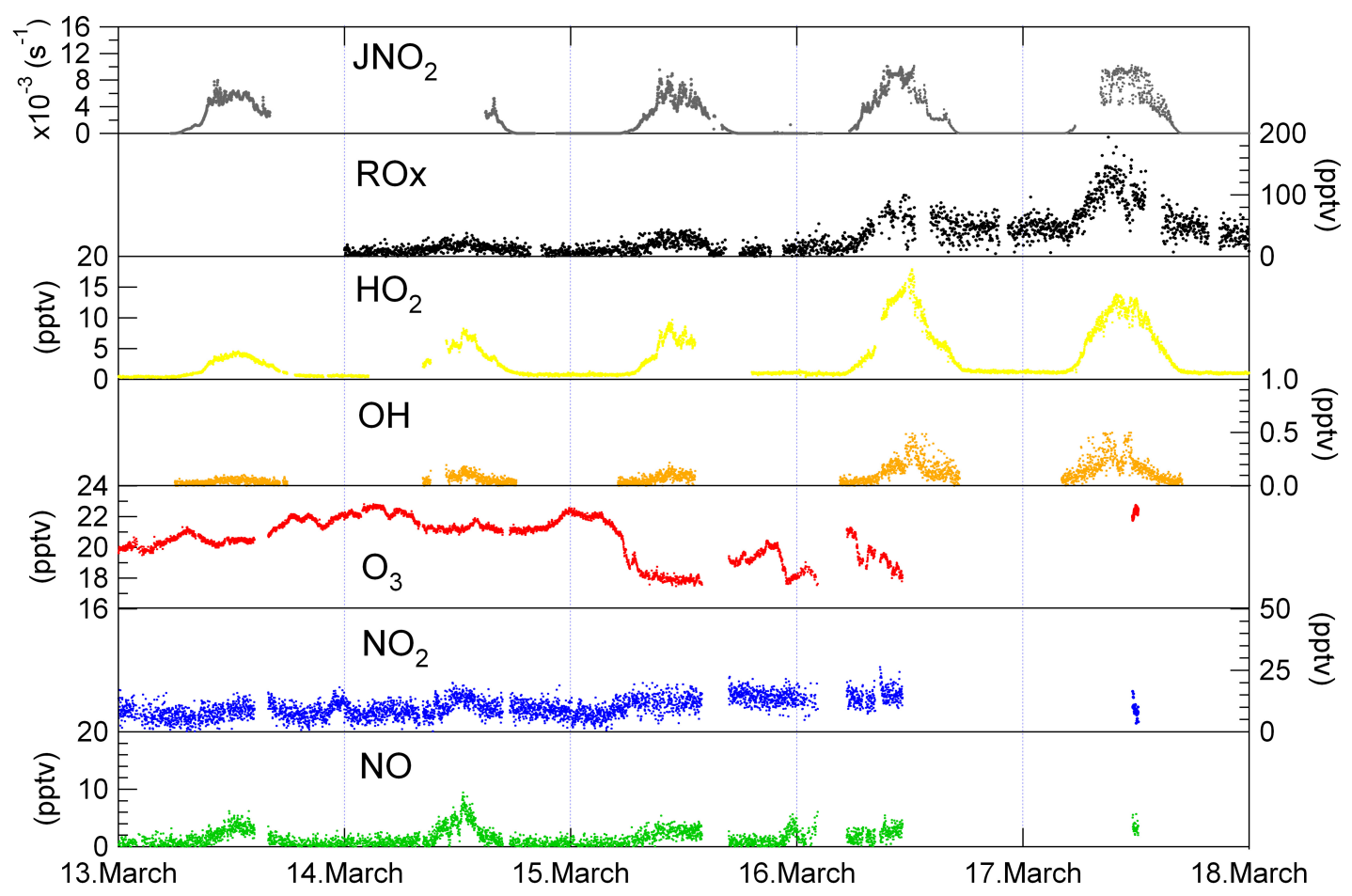

Fig. 8. Measured diurnal profiles of $\mathrm{NO}, \mathrm{NO}_{2}, \mathrm{O}_{3}, \mathrm{~J}_{\mathrm{NO}_{2}}, \mathrm{OH}, \mathrm{HO}_{2}$ and $\mathrm{RO}_{\mathrm{x}}$ (note that $\mathrm{NO}_{\mathrm{x}}$ and $\mathrm{O}_{3}$ data have been filtered for stack emissions).
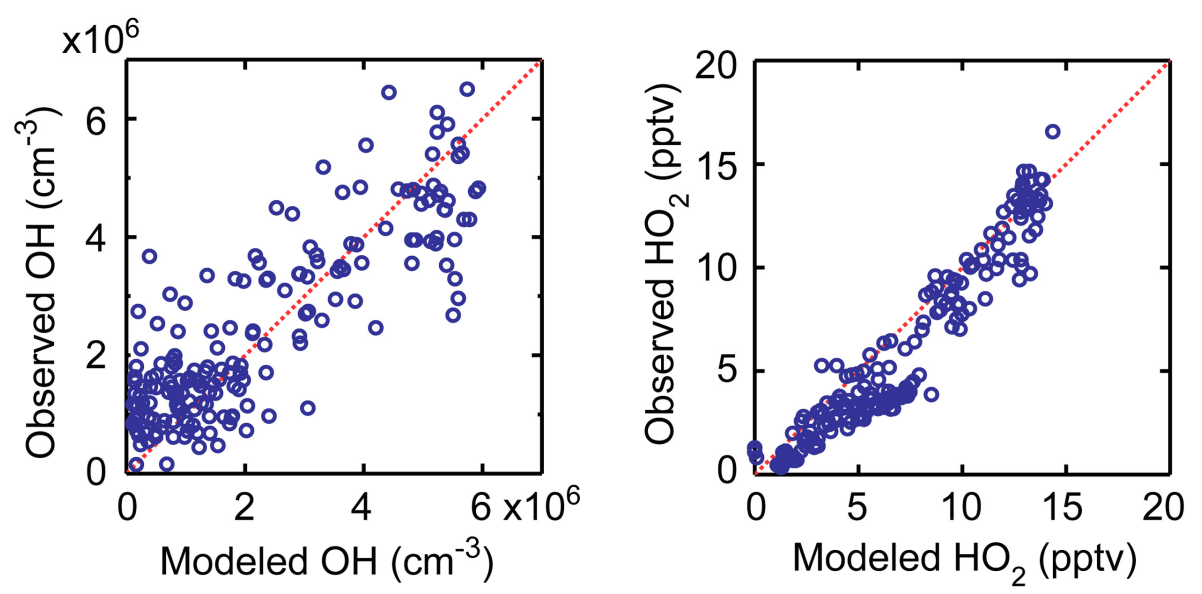

Fig. 9. Comparison of model results with observations of $\mathrm{OH}$ and $\mathrm{HO}_{2}$ (for $\mathrm{NO}<20$ pptv).

$\mathrm{CH}_{3} \mathrm{O}_{2}$ are dominated by the reactions of $\mathrm{CO}$ and $\mathrm{CH}_{4}$ with $\mathrm{OH}$, respectively.

A further test of the assumption of $\mathrm{HO}_{2} \approx \mathrm{CH}_{3} \mathrm{O}_{2} \approx \mathrm{RO}_{2}$ is based on calculations with an atmospheric chemistry general circulation model (AC-GCM). The ECHAM/MESSy Atmospheric Chemistry (EMAC) model describes lower and middle atmosphere processes and their interactions with oceans, land and human influences (Jöckel et al., 2010; Kerkweg et al., 2008). The dynamical core atmospheric general circula- tion model is the 5th generation European Centre Hamburg model ECHAM5 (Roeckner et al., 2006).

EMAC was applied in the T42L90-resolution, i.e. with a spherical truncation of T42 (corresponding to about $2.8^{\circ} \times 2.8^{\circ}$ latitude/longitude) with 90 vertical hybrid pressure levels up to $0.01 \mathrm{hPa}$. The model time step in this resolution is $12 \mathrm{~min}$. Data from the model were sampled at each time step along the OOMPH transect. The results corroborate that for the clean background period until 17 March 2007 


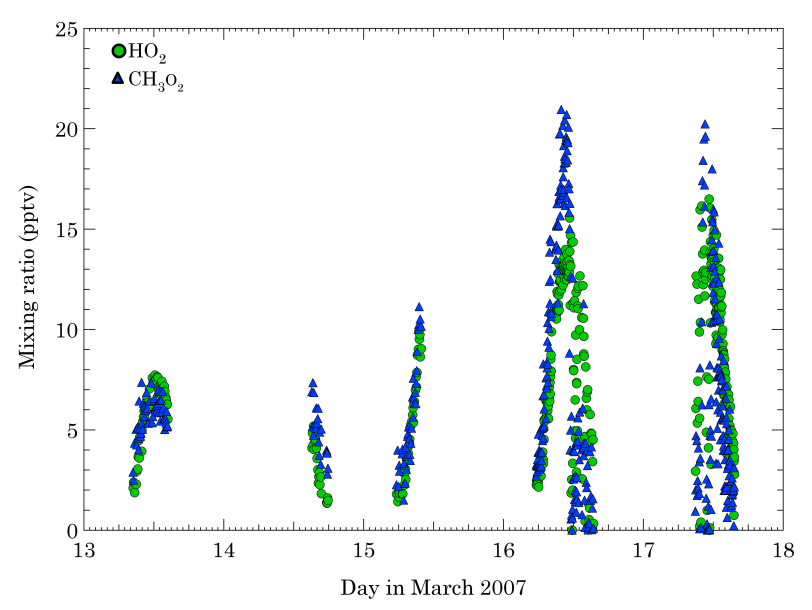

Fig. 10. Results from the chemical box model for daytime $\mathrm{HO}_{2}$ and $\mathrm{CH}_{3} \mathrm{O}_{2}$, obtained by constraining the model with the measurements of non-radical species.

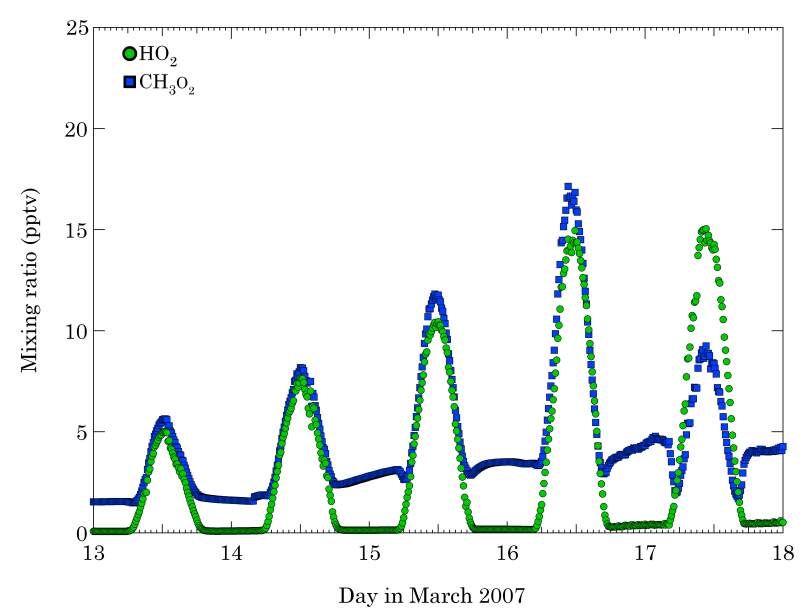

Fig. 11. Results from the global EMAC model for $\mathrm{HO}_{2}$ and $\mathrm{CH}_{3} \mathrm{O}_{2}$. The model grid cells correspond with the locations and time periods of the measurements and the results shown in Fig. 10.

(EMAC predicts somewhat enhanced pollution influences thereafter, related to its coarse resolution), during daylight hours $\mathrm{RO}_{2}$ and $\mathrm{HO}_{2}$ concentrations are about equal (Fig. 11). A closer look at the $\mathrm{RO}_{2}$ specie as predicted by EMAC, i.e. $\mathrm{CH}_{3} \mathrm{O}_{2}, \mathrm{C}_{2} \mathrm{H}_{5} \mathrm{O}_{2}, \mathrm{C}_{3} \mathrm{H}_{7} \mathrm{O}_{2}$ and $\mathrm{C}_{4} \mathrm{H}_{9} \mathrm{O}_{2}$, reveals that $\mathrm{CH}_{3} \mathrm{O}_{2}$ is in fact the dominant $\mathrm{RO}_{2}$ specie and that the mixing ratios of the other species compared to $\mathrm{CH}_{3} \mathrm{O}_{2}$ are negligible. Therefore based on EMAC predictions we can assume that $\mathrm{RO}_{2} \approx \mathrm{CH}_{3} \mathrm{O}_{2}$. As mentioned above, based on previous knowledge this is a reasonable assumption for conditions in which hydrocarbon chemistry is dominated by methane.

The results from both the box model and EMAC corroborate the expectation that $\mathrm{RO}_{2} \approx \mathrm{CH}_{3} \mathrm{O}_{2} \approx \mathrm{HO}_{2}$. Therefore this assumption is valid based on current knowledge

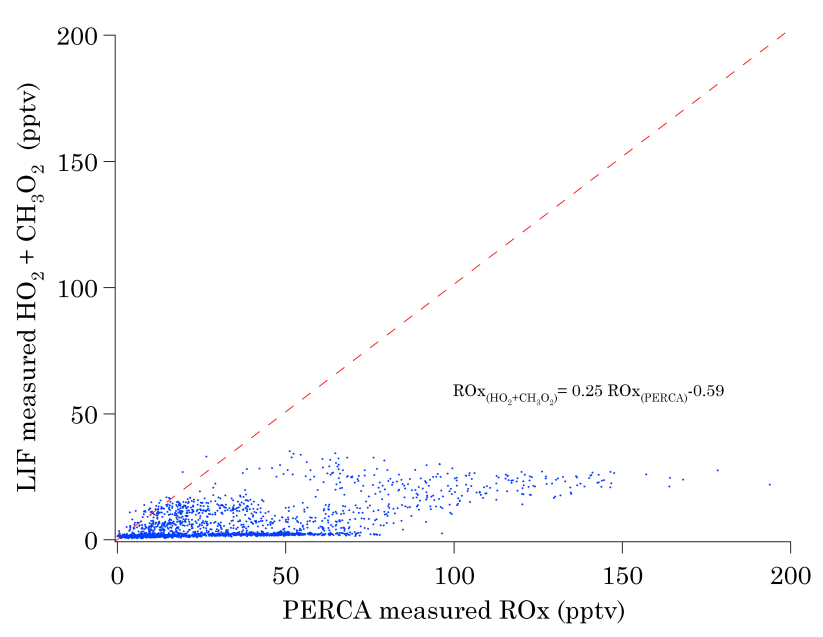

Fig. 12. PERCA measured $\mathrm{RO}_{\mathrm{x}}$ vs. $\mathrm{RO}_{\mathrm{x}}$ based on LIF measured $\mathrm{HO}_{2}$ and an estimate of $\mathrm{CH}_{3} \mathrm{O}_{2}$ (assuming $\mathrm{RO}_{2}=\mathrm{CH}_{3} \mathrm{O}_{2}$ and that $\mathrm{CH}_{3} \mathrm{O}_{2} \sim \mathrm{HO}_{2}$ ). The red dashed line illustrates the 1:1 line.

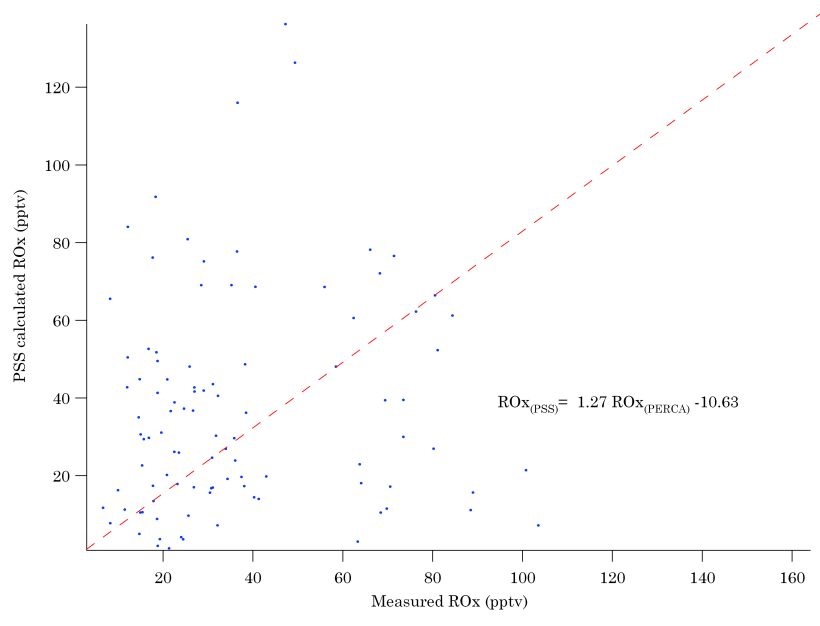

Fig. 13. PERCA measured $\mathrm{RO}_{\mathrm{x}}$ vs. PSS calculated $\mathrm{RO}_{\mathrm{x}}$. The red dashed line illustrates the $1: 1$ line.

of the MBL chemistry and represented by state-of-the-art models. The realistic representation of $\mathrm{HO}_{\mathrm{x}}$ by our constrained box model, in agreement with the global model, is supported by the favourable comparison between the model output and measurements (Fig. 9). However at the same time a significant inconsistency results from the comparison of model calculated and measured $\mathrm{RO}_{\mathrm{x}}$ data. A number of studies have been carried out in which measurements of peroxy radicals have been compared with PSS-based calculations and model results, typically under moderately polluted ( $>50$ pptv $\mathrm{NO}_{\mathrm{x}}$ ) or highly polluted conditions (up to several $\mathrm{ppb}_{\mathrm{v}} \mathrm{NO}_{\mathrm{x}}$ ) (Cantrell et al., 1997; Carpenter et al., 1998; Hauglustaine et al., 1999; Ridley et al., 1992; VolzThomas et al., 2003). Generally, $\mathrm{RO}_{2}$ concentrations calculated by the PSS assumption were significantly higher than the directly measured values. It is remarkable that both our 

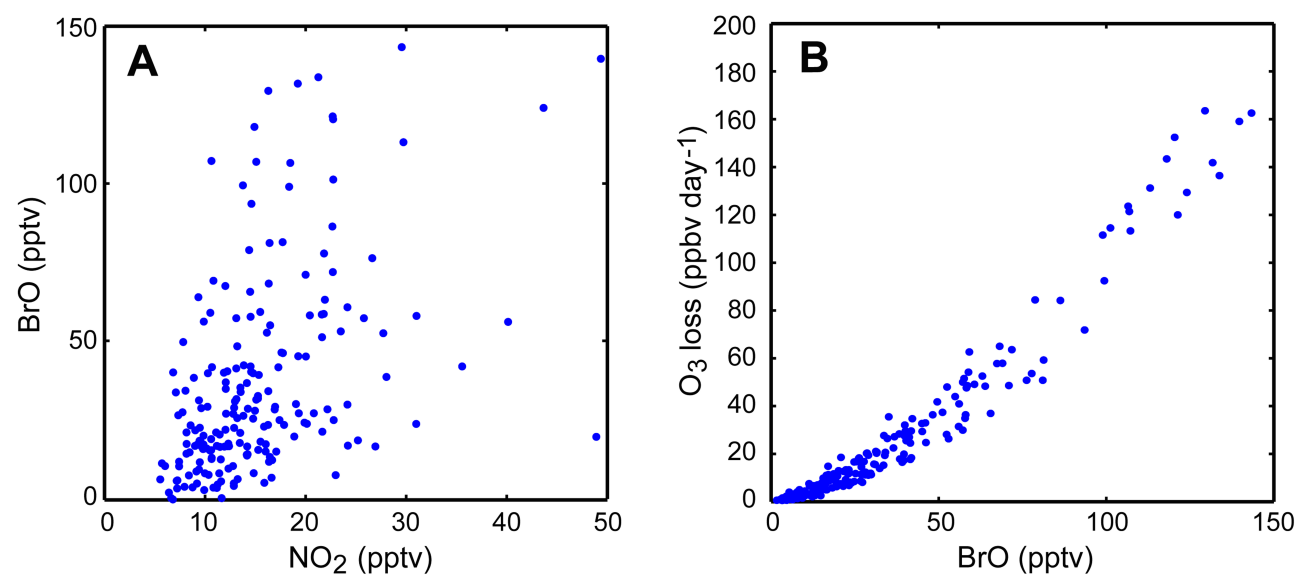

Fig. 14. Results from the chemical box model, constrained by the measurements, assuming a Leighton ratio of $\varphi=1$.

PSS-derived and observed $\mathrm{RO}_{\mathrm{x}}$ are much higher than those predicted by the models and based on previous knowledge, which is demonstrated in Figs. 12 and 13, which show a scatter plot of $\mathrm{RO}_{\mathrm{x}}$ based on LIF measured $\mathrm{HO}_{2}$ and an estimate of $\mathrm{CH}_{3} \mathrm{O}_{2}$ (assuming $\mathrm{RO}_{2}=\mathrm{CH}_{3} \mathrm{O}_{2}$ and that $\mathrm{CH}_{3} \mathrm{O}_{2} \sim \mathrm{HO}_{2}$ ) and PSS derived $\mathrm{RO}_{\mathrm{x}}$ versus measured $\mathrm{RO}_{\mathrm{x}}$, respectively. Figure 12 nicely demonstrates that our understanding of the radical chemistry in the MBL based on our current understanding and also based on box models and 3-D model results accounts for less than $20 \%$ of the measured "peroxy" radi-

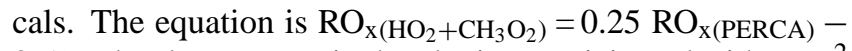
0.59 . The slope we see in the plot is as anticipated with an $R^{2}$ value of 0.64 . Figure 13 confirms that the atmosphere (PSS) and the PERCA see similar results, i.e. similar amounts of "peroxy" radicals or more generally peroxy radicals plus a mystery oxidizer that converts $\mathrm{NO}$ to $\mathrm{NO}_{2}$ and undergoes amplification in the PERCA. The equation in this case is $\mathrm{RO}_{\mathrm{x}(\mathrm{PSS})}=1.27 \mathrm{RO}_{\mathrm{x}(\mathrm{PERCA})}-10.63$. Although the data scatter around the 1:1 line, the correlation coefficient is rather poor.

This difference can be interpreted in two ways. First there may be systematic errors involved in measuring and calculating $\mathrm{RO}_{\mathrm{x}}$ and $\mathrm{RO}_{2}$. Second there is an unknown photochemical oxidant that converts $\mathrm{NO}$ into $\mathrm{NO}_{2}$. The process apparently maintains the $\mathrm{OH} / \mathrm{HO}_{2}$ relationship, as indicated by Fig. 9; and the effects vanish as $\mathrm{NO}_{\mathrm{x}}$ increases. The fact that the $\mathrm{RO}_{\mathrm{x}}$ mixing ratios are so high suggests that the PERCA instrument is also sensitive to the unknown oxidant (to be discussed below). Actually, the $\mathrm{RO}_{\mathrm{x}}$ measurements provide independent observational support of an unknown oxidant that causes the anomalous Leighton ratios.

\subsection{BLC and potential interfering species}

The peak absorption cross section for $\mathrm{NO}_{2}$ is at $390-400 \mathrm{~nm}$, i.e. the wavelength range of the LEDs. This precludes the conversion of potential interfering species such as HONO, $\mathrm{NO}_{3}$ and PAN (Fig. 2).
Furthermore, based on the very low PAN concentrations calculated by our atmospheric chemistry general circulation model (EMAC, discussed in article) and PAN measurements during the campaign, which were below the DL of the instrument (10 pptv), potential interferences from this species are highly unlikely, as several hundred pptv would be required to cause significant effects through thermal decomposition. Also due to the relatively low temperatures during the cruise, the lifetime of PAN was calculated to be about 1.2 days, indicating that it is thermally stable under the measurement conditions.

To investigate which species could cause possible interferences in the BLC, the absorption cross sections (ACS) of many species were studied and compared to the ACS of $\mathrm{NO}_{2}$ for three different wavelengths, i.e. 390, 395 and $400 \mathrm{~nm}$ (source: the MPI-Mainz spectral atlas at http://www. atmosphere.mpg.de/enid/2295). Species which have been suggested as potentially interfering are PAN, nitrous and nitric acid ( $\mathrm{HONO}$ and $\mathrm{HNO}_{3}$ ), alkyl nitrates (e.g. methyl nitrate and ethyl nitrate), and halogen nitrates $\left(\mathrm{BrONO}_{2}\right.$, $\mathrm{ClONO}_{2}, \mathrm{ClNO}, \mathrm{ClNO}_{2}$ and $\mathrm{BrNO}_{2}$ ). The results of this study are summarized in Table 5.

The $\mathrm{NO}_{2}$ equivalent of each species needed to produce 7 pptv of additional $\mathrm{NO}_{2}$ was calculated and is listed in Table 5. A dash in the table means that there is no corresponding ACS for the species in the wavelength of interest.

From Table 5 it can be concluded that these species may not be expected to cause significant interferences in the BLC. $\mathrm{BrNO}_{2}$ is the only specie with an ACS close enough to that of $\mathrm{NO}_{2}$ at the wavelength of interest. However calculation of the mixing ratio of $\mathrm{BrNO}_{2}$ needed to produce $7 \mathrm{pptv}$ of $\mathrm{NO}_{2}$ shows that on average 26 pptv would be required, which we consider highly unlikely in view of the model calculations presented in the article. 
Table 5. Absorption cross section of potentially interfering species.

\begin{tabular}{|c|c|c|c|c|}
\hline & ASC at $390 \mathrm{~nm}$ & ASC at $395 \mathrm{~nm}$ & $\mathrm{ASC}$ at $400 \mathrm{~nm}$ & $\begin{array}{r}\mathrm{NO}_{2} \text { equivalent } \\
(7 \mathrm{pptv})\end{array}$ \\
\hline $\mathrm{NO}_{2}$ & $5.90 \times 10^{-19}$ & $6.10 \times 10^{-19}$ & $6.50 \times 10^{-19}$ & - \\
\hline $\mathrm{BrONO}_{2}$ & $2.90 \times 10^{-20}$ & $2.60 \times 10^{-20}$ & $2.30 \times 10^{-20}$ & 142 \\
\hline $\mathrm{ClONO}_{2}$ & $9.10 \times 10^{-22}$ & $7.60 \times 10^{-22}$ & $6.40 \times 10^{-22}$ & 4538 \\
\hline $\mathrm{CINO}$ & $6.86 \times 10^{-20}$ & $5.97 \times 10^{-20}$ & $5.13 \times 10^{-20}$ & 60 \\
\hline $\mathrm{ClNO}_{2}$ & $4.75 \times 10^{-21}$ & - & $3.27 \times 10^{-21}$ & 869 \\
\hline $\mathrm{BrNO}_{2}$ & $1.60 \times 10^{-19}$ & $1.50 \times 10^{-19}$ & $1.40 \times 10^{-19}$ & 26 \\
\hline HONO & $2.40 \times 10^{-20}$ & $6.00 \times 10^{-21}$ & - & 172 \\
\hline PAN & - & - & - & - \\
\hline $\mathrm{HNO}_{3}$ & - & - & - & - \\
\hline Methyl nitrate & - & - & - & - \\
\hline Ethyl nitrate & - & - & - & - \\
\hline
\end{tabular}

\subsection{PERCA method and potential interferences}

The most widely used method to measure $\mathrm{RO}_{\mathrm{x}}$ is based on the Peroxy Radical by Chemical Amplification (PERCA) technique (Cantrell et al., 1993; Penkett et al., 1997). NO is added to the air mixture containing $\mathrm{RO}_{2}$ and $\mathrm{HO}_{2}$, yielding $\mathrm{NO}_{2}$, which can be detected by several methods. The PERCA method was also employed in our measurement campaign (Fleming et al., 2006). An inherent problem is that oxidants in addition to $\mathrm{RO}_{2} / \mathrm{HO}_{2}$ that convert $\mathrm{NO}$ into $\mathrm{NO}_{2}$ are detected ambiguously. For example, it has been shown that halogen oxides $(\mathrm{ClO})$, especially in the presence of $\mathrm{CO}$, catalytically oxidize NO. The measurement principle of the PERCA method is based on the $\mathrm{OH} / \mathrm{HO}_{2}$ radical catalysed simultaneous chain oxidation of $\mathrm{CO}$ to $\mathrm{CO}_{2}$ and $\mathrm{NO}$ to $\mathrm{NO}_{2}$ :

$\mathrm{HO}_{2}+\mathrm{NO} \rightarrow \mathrm{NO}_{2}+\mathrm{OH}$

$\mathrm{OH}+\mathrm{CO} \rightarrow \mathrm{CO}_{2}+\mathrm{H}$

$\mathrm{H}+\mathrm{O}_{2}+\mathrm{M} \rightarrow \mathrm{HO}_{2}+\mathrm{M}$

$\mathrm{RO}_{2}$ measurement first requires the conversion of $\mathrm{RO}_{2}$ to $\mathrm{HO}_{2}$ via the following reactions:

$\mathrm{RO}_{2}+\mathrm{NO} \rightarrow \mathrm{NO}_{2}+\mathrm{RO}$

$\mathrm{RO}+\mathrm{O}_{2} \rightarrow \mathrm{RCHO}+\mathrm{HO}_{2}$

$\rightarrow \mathrm{R}-\mathrm{CO}-\mathrm{R}+\mathrm{HO}_{2}$

Subsequently $\mathrm{HO}_{2}$ is detected through the same cycle as the first three reactions mentioned above. Therefore any oxidant that converts $\mathrm{NO}$ to $\mathrm{NO}_{2}$ and has a sufficiently long chain length (i.e. the number of conversion cycles that occurs before termination) can be detected via the chemical amplification method. In a study by (Perner et al., 1999) it was observed that the method is sensitive to $\mathrm{ClO}_{\mathrm{x}}\left(\mathrm{Cl}+\mathrm{ClO}+\mathrm{ClO}_{2}\right)$.
It was found that $\mathrm{ClO}_{\mathrm{x}}$ is reduced by $\mathrm{NO}$ to $\mathrm{Cl}$ atoms which react with $\mathrm{CO}$ in the presence of $\mathrm{O}_{2}$ :

$\mathrm{ClO}+\mathrm{NO} \rightarrow \mathrm{Cl}+\mathrm{NO}_{2}$

$\mathrm{Cl}+\mathrm{CO}+\mathrm{M} \rightarrow \mathrm{ClCO}+\mathrm{M}$

The reaction sequence which is initiated oxidizes $\mathrm{CO}$ to $\mathrm{CO}_{2}$ and $\mathrm{NO}$ to $\mathrm{NO}_{2}$ :

$$
\begin{aligned}
& \mathrm{ClCO}+\mathrm{O}_{2}+\mathrm{M} \rightarrow \mathrm{ClCO}_{3}+\mathrm{M} \\
& \mathrm{ClCO}_{3}+\mathrm{NO} \rightarrow \mathrm{Cl}+\mathrm{CO}_{2}+\mathrm{NO}_{2}
\end{aligned}
$$

The chain length for $\mathrm{ClO}_{\mathrm{x}}$ species in the study by Perner et al. was reported to be $300 \pm 60$. In parallel peroxy radicals are indicated with a chain length of $160 \pm 15$. Therefore the chain length for $\mathrm{ClO}_{\mathrm{x}}$ is approximately a factor of two larger than that of the peroxy radicals. It is actually possible that the $\mathrm{ClO}_{\mathrm{x}}$ chain length could be up to a factor of 10 higher compared to the peroxy radical chain length (J. N. Crowley, personal communication, 2009). This would of course have a significant impact on the total observed " $\mathrm{RO}_{\mathrm{x}}$ signal". Thus the chemical amplification method is not specific and does not indicate which radical chain is observed. Therefore the PERCA signal can be defined as:

PERCA signal $=\mathrm{RO}_{2}+\mathrm{RO}+\mathrm{HO}_{2}+\mathrm{OH}+\mathrm{X}$

$\mathrm{X}$ in the above equation is the additional unknown oxidant that can oxidize $\mathrm{NO}$ to $\mathrm{NO}_{2}$ in the atmosphere and therefore lead to the high $\mathrm{NO}_{2}$ levels measured during the campaign.

The possibility that unidentified NO-to- $\mathrm{NO}_{2}$ conversions have affected our PERCA measurements actually reconciles the above two interpretations. The unexpected high $\mathrm{RO}_{\mathrm{x}}$ mixing ratios as measured with the PERCA instrument, being up to an order of magnitude higher than of measured $\mathrm{HO}_{2}$ and of modelled $\mathrm{HO}_{2}$ and $\mathrm{RO}_{2}$ provides independent observational support for the presence of an unknown oxidant. Furthermore, its production is likely to be catalytic as it produces a strong signal in the PERCA instrument. 


\subsection{Halogen monoxides, DMS and the Leighton ratio}

Several researchers have proposed that halogen monoxides can represent an "unknown oxidant" and drive $\varphi$ away from unity, although their studies did not pertain to baseline MBL chemistry (Mannschreck et al., 2004; Matsumoto et al., 2006). Further, Read et al. (2008) conclude that biologically active regions of the tropical Atlantic Ocean release reactive halogens (up to 2.5 pptv $\mathrm{BrO}$ ) and destroy ozone. This contrasts with our measurements in a region of very low biological activity. The part of the numerator in Eq. (2) between parentheses would have to be expanded by another term $k_{6}[\mathrm{XO}]$, with X representing e.g. bromine. Both our chemical box and global chemistry-transport models include comprehensive descriptions of halogen chemistry in the MBL. Our model calculations indicate only very low concentrations of $\mathrm{BrO}$ in the measurement region (well below $1 \mathrm{pptv}$ ), one reason being that in the remote MBL the sea salt aerosol is hardly acidified by strong acids (e.g. $\mathrm{H}_{2} \mathrm{SO}_{4}$ ) of natural and anthropogenic origin. Back-calculating from Eq. (2), assuming that $\left[\mathrm{NO}_{2}\right]_{\text {observed }} /\left[\mathrm{NO}_{2}\right]_{\text {calculated }}$ is unity, implies that a $\mathrm{BrO}$ mixing ratio up to $\sim 100 \mathrm{pptv}$ would be required. This would represent a "bromine explosion" leading to the depletion of $\mathrm{O}_{3}$ and $\mathrm{NO}_{\mathrm{x}}$, which is not observed.

We have used the chemical box model, which includes a comprehensive description of halogen chemistry (Kerkweg et al., 2008) to investigate the potential role of bromine in the observed deviation of the Leighton ratio. We constrained the model with the observations and applied an artificial emission of $\mathrm{Br}_{2}$ from the sea salt aerosol (or a surface source) and increased the entrainment of ozone from the free troposphere to prevent its complete chemical destruction. For a Leighton ratio $\phi=1$ the simulated mixing ratio of $\mathrm{BrO}$ ranges from a few to more than $100 \mathrm{pptv}$ at low to high solar intensity, respectively (Fig. 14a). These BrO mixing ratios are orders of magnitude higher than those simulated with a threedimensional global model (Kerkweg et al., 2008). If the marine boundary layer chemistry would sustain such high $\mathrm{BrO}$ mixing ratios, it would be extremely difficult to explain the observed $\mathrm{O}_{3}$ levels of $\sim 20 \mathrm{ppb}_{\mathrm{v}}$. Figure $14 \mathrm{~b}$ shows that 10 30 pptv $\mathrm{BrO}$, for example, destroys $5-15 \mathrm{ppb}_{\mathrm{v}} \mathrm{O}_{3}$ during the day, which would give rise to a strong diurnal cycle of $\mathrm{O}_{3}$ in the boundary layer, which is not observed. Although we do not exclude that halogen chemistry takes place, it seems highly unlikely that reactive bromine accounts for the "mystery" oxidant.

The contribution of DMS has been considered as a potential source of peroxy radicals as this compound was measured during the campaign. However, the ship sailed across regions with very low biological activity at the time of the measurements, and mixing ratios of DMS, and other volatile organic compounds (VOCs) such as isoprene, were rather low, i.e. DMS averaged about $50 \mathrm{pptv}$, which is too low to have a significant effect.

\subsection{Uncertainty related to rate coefficients}

The uncertainty related to the rate coefficients of relevant reactions, $k_{i}$, is of course part of the overall uncertainty of the PSS calculations. It is believed that whilst $k_{i}$ does in fact contribute to the overall uncertainty of the results, there is little dispute over the actual $k_{i}$ values themselves. This was noticed in the sensitivity tests carried out on the PSS calculations using two studies of rate coefficients (e.g., Atkinson et al., 2004; Sander et al., 2006).

The two rate coefficients agree well within the range of uncertainty. Therefore it is concluded that the large deviations seen in the Leighton ratios cannot be due to the relatively insignificant uncertainty in the $k_{i}$ values.

The assumption that the reaction rate coefficients of $\mathrm{RO}_{2}$ with $\mathrm{NO}$ are similar to that of $\mathrm{HO}_{2}$ has been commonly used in the past. However, it has been suggested that the reaction rate coefficients of $\mathrm{RO}_{2}$ and $\mathrm{HO}_{2}$ could be critical for PSS calculations of $\mathrm{RO}_{\mathrm{x}}$ (Matsumoto et al., 2006). Therefore a sensitivity test was carried out in relation to rate coefficients, in this case specifically for $\mathrm{RO}_{\mathrm{x}}$ calculated from the PSS expression ( $\left.\left[\mathrm{RO}_{\mathrm{x}}\right]_{\mathrm{PSS}}\right)$. It was found that the reaction rates of $\mathrm{NO}$ with $\mathrm{HO}_{2}$ and $\mathrm{RO}_{2}$ are critical for the PSS estimation and that $\left[\mathrm{RO}_{\mathrm{x}}\right]_{\text {PSS }}$ can be influenced by uncertainties in the rate coefficients. Therefore it is recommended that the above assumption should be practiced with caution.

\section{Conclusions}

Our measurements provide compelling evidence of the presence of an unknown oxidant. It might only convert NO into $\mathrm{NO}_{2}$, but also has the potential of participating in catalytic oxidant cycles, as indicated by the PERCA measurements. Note that even though the uncertainties increase with decreasing $\mathrm{NO}_{2}$, at the very lowest levels of 3-5 pptv $\varphi$ approaches one (Fig. 4), which argues against a measurement error to explain the exponentially increasing $\varphi$-values at $\mathrm{NO}_{2}$ mixing ratios up to $20 \mathrm{pptv}$. Although it is widely accepted that the oxidation chemistry of the troposphere is dominated by reactions with OH (Crutzen et al., 1994; Heard and Pilling, 2003; Logan et al., 1981), a growing number of studies exposes discrepancies between model calculations and observations in low- $\mathrm{NO}_{\mathrm{x}}$ conditions (Brune et al., 1998; Faloona et al., 2000; Hofzumahaus et al., 2009; Lelieveld et al., 2008; Stevens et al., 1997; Thornton et al., 2002). It is noteworthy that models and measurements of $\mathrm{HO}_{\mathrm{x}}$ in the remote MBL generally agree well, which has been optimistically interpreted as a consistent understanding of baseline photochemistry (Heard and Pilling, 2003; Sommariva et al., 2004). However, taking all indications into account rather suggests that something important is missing in our understanding of baseline photochemistry. 


\section{Appendix A}

\section{Abbreviations and acronyms}

\begin{tabular}{|c|c|}
\hline $\mathrm{ACS}$ & Absorption cross sections \\
\hline BLC & Blue light converter \\
\hline $\mathrm{CE}$ & Conversion efficiency \\
\hline $\mathrm{CH}_{3} \mathrm{O}_{2}$ & Methyl peroxy radical \\
\hline CLD & Chemiluminescence detector \\
\hline DL & Detection limit \\
\hline DMS & dimethyl sulfide \\
\hline ECHAM & $\begin{array}{l}\text { European Centre Hamburg } \\
\text { general circulation model }\end{array}$ \\
\hline EMAC & $\begin{array}{l}\text { ECHAM/MESSy Atmospheric } \\
\text { chemistry model }\end{array}$ \\
\hline GPT & Gas phase titration \\
\hline $\mathrm{HO}_{2}$ & Hydroperoxy radical \\
\hline$J_{\mathrm{NO}_{2}}$ & Photolysis rate of $\mathrm{NO}_{2}$ \\
\hline LED & Light emitting diodes \\
\hline LIDAR & Laser detection and ranging \\
\hline LIF & Laser induced fluorescence \\
\hline MBL & Marine boundary layer \\
\hline MD & Marion Dufresne \\
\hline MESSy & Modular earth sub-model system \\
\hline MPI & Max Planck Institute \\
\hline NO & Nitrogen oxide \\
\hline $\mathrm{NO}_{2}$ & Nitrogen dioxide \\
\hline $\mathrm{NO}_{\mathrm{x}}$ & $\begin{array}{l}\text { Total sum of active nitrogen } \\
\text { oxides }\left(\mathrm{NO}+\mathrm{NO}_{2}\right)\end{array}$ \\
\hline $\mathrm{OH}$ & Hydroxyl radical \\
\hline OOMPH & $\begin{array}{l}\text { Organics over Ocean Modifying Particles } \\
\text { in both hemispheres }\end{array}$ \\
\hline PAN & Peroxy acetyl nitrate \\
\hline PERCA & Peroxy radical chemical amplifier \\
\hline $\mathrm{ppb}_{\mathrm{v}}$ & parts per billion \\
\hline pptv & parts per trillion \\
\hline PSS & Photostationary state \\
\hline $\mathrm{RO}_{2}$ & Organic peroxy radical \\
\hline $\mathrm{RO}_{\mathrm{x}}$ & Total sum of organic peroxy radicals \\
\hline SA & Synthetic air \\
\hline Sccm & Standard cubic centimetres per minute \\
\hline SLM & Standard liter per minute \\
\hline STDEV & Standard deviation \\
\hline UV & Ultraviolet \\
\hline VOC & Volatile organic compound \\
\hline
\end{tabular}

\section{Supplementary material related to this article is available online at: http://www.atmos-chem-phys.net/11/8497/2011/ acp-11-8497-2011-supplement.pdf.}

Acknowledgements. We are grateful to the OOMPH campaign (MD160) team members: U. Parchatka, C. Gurk, R. Königstedt, S. Wong-Zehnpfennig, S. Zorn, T. Custer, V. Sinha, V. Gros, D. Kubistin and M. Rudolf. We thank the Modular Earth Submodel
System (MESSy) team for model support, in particular P. Jöckel. We also thank H. Wernli for providing back trajectory data, and J. Crowley for comments on the manuscript. The authors are grateful for logistical support from the IPEV during the Southern Ocean cruise. The OOMPH project was funded under the EU sixth framework program (018419).

The service charges for this open access publication have been covered by the Max Planck Society.

Edited by: R. Ebinghaus

\section{References}

Atkinson, R., Baulch, D. L., Cox, R. A., Crowley, J. N., Hampson, R. F., Hynes, R. G., Jenkin, M. E., Rossi, M. J., and Troe, J.: Evaluated kinetic and photochemical data for atmospheric chemistry: Volume $\mathrm{I}-$ gas phase reactions of $\mathrm{O}_{\mathrm{x}}, \mathrm{HO}_{\mathrm{x}}, \mathrm{NO}_{\mathrm{x}}$ and $\mathrm{SO}_{\mathrm{x}}$ species, Atmos. Chem. Phys., 4, 1461-1738, doi:10.5194/acp-41461-2004, 2004.

Brune, W. H., Faloona, I. C., Tan, D., Weinheimer, A. J., Campos, T., Ridley, B. A., Vay, S. A., Collins, J. E., Sachse, G. W., Jaegle, L., and Jacob, D. J.: Airborne in-situ $\mathrm{OH}$ and $\mathrm{HO}_{2}$ observations in the cloud-free troposphere and lower stratosphere during SUCCESS, Geophys. Res. Lett., 25, 1701-1704, 1998.

Cantrell, C. A., Shetter, R. E., Lind, J. A., McDaniel, A. H., Calvert, J. G., Parrish, D. D., Fehsenfeld, F. C., Buhr, M. P., and Trainer, M.: An Improved Chemical Amplifier Technique for Peroxy Radical Measurements, J. Geophys. Res.-Atmos., 98, 2897-2909, 1993.

Cantrell, C. A., Shetter, R. E., Calvert, J. G., Eisele, F. L., Williams, E., Baumann, K., Brune, W. H., Stevens, P. S. and Mather, J. H.: Peroxy radicals from photostationary state deviations and steady state calculations during the tropospheric $\mathrm{OH}$ photochemistry experiment at Idaho Hill, Colorado, 1993, J. Geophys. Res.Atmos., 102, 6369-6378, 1997.

Carpenter, L. J., Clemitshaw, K. C., Burgess, R. A., Penkett, S. A., Cape, J. N. and McFadyen, G. C.: Investigation and evaluation of the $\mathrm{NO}_{\mathrm{x}} / \mathrm{O}_{3}$ photochemical steady state, Atmos. Environ., 32, 3353-3365, 1998.

Crutzen, P. J., Lelieveld, J., and Bruehl, C.: Advances in Environmental Science and Technology, Wiley, New York, 1994.

Faloona, I., Tan, D., Brune, W. H., Jaegle, L., Jacob, D. J., Kondo, Y., Koike, M., Chatfield, R., Pueschel, R., Ferry, G., Sachse, G., Vay, S., Anderson, B., Hannon, J., and Fuelberg, H.: Observations of $\mathrm{HO}_{\mathrm{x}}$ and its relationship with $\mathrm{NO}_{\mathrm{x}}$ in the upper troposphere during SONEX, J. Geophys. Res.-Atmos., 105, 37713783, 2000.

Fleming, Z. L., Monks, P. S., Rickard, A. R., Bandy, B. J., Brough, N., Green, T. J., Reeves, C. E., and Penkett, S. A.: Seasonal dependence of peroxy radical concentrations at a Northern hemisphere marine boundary layer site during summer and winter: evidence for radical activity in winter, Atmos. Chem. Phys., 6, 5415-5433, doi:10.5194/acp-6-5415-2006, 2006.

Hauglustaine, D. A., Madronich, S., Ridley, B. A., Flocke, S. J., Cantrell, C. A., Eisele, F. L., Shetter, R. E., Tanner, D. J., Ginoux, P., and Atlas, E. L.: Photochemistry and budget of ozone during the Mauna Loa Observatory Photochemistry Experiment 
(MLOPEX 2), J. Geophys. Res.-Atmos., 104, 30275-30307, 1999.

Heard, D. E. and Pilling, M.J.: Measurement of $\mathrm{OH}$ and $\mathrm{HO}_{2}$ in the troposphere, Chem. Rev., 103, 5163-5198, 2003.

Hofzumahaus, A., Rohrer, F., Lu, K. D., Bohn, B., Brauers, T., Chang, C. C., Fuchs, H., Holland, F., Kita, K., Kondo, Y., Li, X., Lou, S. R., Shao, M., Zeng, L. M., Wahner, A., and Zhang, Y. H.: Amplified Trace Gas Removal in the Troposphere, Science, 324, 1702-1704, 2009.

Hosaynali Beygi, Z.: Oxidation photochemistry in the remote marine boundary layer, PhD Thesis, International Max Planck Research School, Johannes Gutenberg University Mainz, Germany, 2010.

Jöckel, P., Kerkweg, A., Pozzer, A., Sander, R., Tost, H., Riede, H., Baumgaertner, A., Gromov, S., and Kern, B.: Development cycle 2 of the Modular Earth Submodel System (MESSy2), Geosci. Model Dev., 3, 717-752, doi:10.5194/gmd-3-717-2010, 2010.

Junkermann, W., Platt, U., and Volz Thomas, A.: A photoelectric detector for the measurement of photolysis frequencies of Ozone and other atmospheric molecules, J. Atmos. Chem., 8, 203-227, 1989.

Kerkweg, A., Jöckel, P., Warwick, N., Gebhardt, S., Brenninkmeijer, C. A. M., and Lelieveld, J.: Consistent simulation of bromine chemistry from the marine boundary layer to the stratosphere - Part 2: Bromocarbons, Atmos. Chem. Phys., 8, 5919-5939, doi:10.5194/acp-8-5919-2008, 2008.

Kubistin, D., Harder, H., Martinez, M., Rudolf, M., Sander, R., Bozem, H., Eerdekens, G., Fischer, H., Gurk, C., Klpfel, T., Königstedt, R., Parchatka, U., Schiller, C. L., Stickler, A., Taraborrelli, D., Williams, J., and Lelieveld, J.: Hydroxyl radicals in the tropical troposphere over the Suriname rainforest: comparison of measurements with the box model MECCA, Atmos. Chem. Phys., 10, 9705-9728, doi:10.5194/acp-10-97052010, 2010.

Leighton, P. A.: Photochemistry of air pollution, Phys. Chem., 9, 300 pp., 1961

Lelieveld, J., Butler, T. M., Crowley, J. N., Dillon, T. J., Fischer, H., Ganzeveld, L., Harder, H., Lawrence, M. G., Martinez, M., Taraborrelli, D., and Williams, J.: Atmospheric oxidation capacity sustained by a tropical forest, Nature, 452, 737-740, 2008.

Levy, H.: Normal Atmosphere - Large Radical and Formaldehyde Concentrations Predicted, Science, 173, 141-143, 1971.

Logan, J. A.: Tropospheric chemistry a global perspective, Am. Chem. Soc., 86, 7210-7254, 1981.

Mannschreck, K., Gilge, S., Plass-Duelmer, C., Fricke, W., and Berresheim, H.: Assessment of the applicability of $\mathrm{NO}-\mathrm{NO}_{2}-$ $\mathrm{O}_{3}$ photostationary state to long-term measurements at the Hohenpeissenberg GAW Station, Germany, Atmos. Chem. Phys., 4, 1265-1277, doi:10.5194/acp-4-1265-2004, 2004.

Martinez, M., Harder, H., Kubistin, D., Rudolf, M., Bozem, H., Eerdekens, G., Fischer, H., Klpfel, T., Gurk, C., Königstedt, R., Parchatka, U., Schiller, C. L., Stickler, A., Williams, J., and Lelieveld, J.: Hydroxyl radicals in the tropical troposphere over the Suriname rainforest: airborne measurements, Atmos. Chem. Phys., 10, 3759-3773, doi:10.5194/acp-10-3759-2010, 2010.

Matsumoto, J., Kosugi, N., Nishiyama, A., Isozaki, R., Sadanaga, Y., Kato, S., Bandow, H., and Kajii, Y.: Examination on photostationary state of $\mathrm{NO}_{\mathrm{x}}$ in the urban atmosphere in Japan, Atmos. Environ., 40, 3230-3239, 2006.
Monks, P., Carpenter, L. J., Penkett, S. A., Ayers, G. P., Gillett, R. W., Galbally, I. E., and Meyer, C. P.: Fundamental ozone photochemistry in the remote marine boundary layer: the soapex experiment, measurement and theory, Atmos. Environ., 32, 36473664, 1998.

Parker, A. E., Monks, P. S., Wyche, K. P., Balzani-Lööv, J. M., Staehelin, J., Reimann, S., Legreid, G., Vollmer, M. K., and Steinbacher, M.: Peroxy radicals in the summer free troposphere: seasonality and potential for heterogeneous loss, Atmos. Chem. Phys., 9, 1989-2006, doi:10.5194/acp-9-1989-2009, 2009.

Parrish, D. D., Trainer, M., Williams, E. J., Fahey, D. W., Hubler, G., Eubank, C. S., Liu, S. C., Murphy, P. C., Albritton, D. L., and Fehsenfeld, F. C.: Measurements of the $\mathrm{NO}_{\mathrm{x}}-\mathrm{O}_{3}$ Photostationary State at Niwot Ridge, Colorado, J. Geophys. Res.-Atmos., 91, 5361-5370, 1986.

Penkett, S. A., Monks, P. S., Carpenter, L. J., Clemitshaw, K. C., Ayers, G. P., Gillett, R. W., Galbally, I. E., and Meyer, C. P.: Relationships between ozone photolysis rates and peroxy radical concentrations in clean marine air over the Southern Ocean, J. Geophys. Res.-Atmos., 102, 12805-12817, 1997.

Perner, D., Arnold, T., Crowley, J., Klupfel, T., Martinez, M., and Seuwen, R.: The measurement of active chlorine in the atmosphere by chemical amplification, J. Atmos. Chem., 34, 9-20, 1999.

Read, K. A., Mahajan, A. S., Carpenter, L. J., Evans, M. J., Faria, B. V. E., Heard, D. E., Hopkins, J. R., Lee, J. D., Moller, S. J., Lewis, A. C., Mendes, L., McQuaid, J. B., Oetjen, H., SaizLopez, A., Pilling, M. J., and Plane, J. M. C.: Extensive halogenmediated ozone destruction over the tropical Atlantic Ocean, Nature, 453, 1232-1235, 2008.

Ridley, B. A., Madronich, S., Chatfield, R. B., Walega, J. G., Shetter, R. E., Carroll, M. A., and Montzka, D. D.: Measurements and model simulations of the photostationary state during the MaunaLoa-Observatory photochemistry experiment - Implications for radical concentrations and Ozone production and loss rates, J. Geophys. Res.-Atmos., 97, 10375-10388, 1992.

Roeckner, E., Brokopf, R., Esch, M., Giorgetta, M., Hagemann, S., Kornblüh, Manzini, L. E., Schlese, U., and Schulzweida, U.: Sensitivity of simulated climate to horizontal and vertical resolution in the ECHAM5 atmosphere model, J. Climate, 19, 37713791, 2006.

Sander, S. P., Golden, D. M., Kurylo, M. J., Moortgat, G. K., Wine, P. H., Ravishankara, A. R., Kolb, C. E., Molina, M. J., FinlaysonPitts, B. J., Huie, R. E., and Orkin, V. L.: Chemical Kinetics and photochemical data for use in stratospheric modeling - evaluation number 15, Jet Propulsion Laboratory, California Institute of Technology, California, 2006

Sommariva, R., Haggerstone, A.-L., Carpenter, L. J., Carslaw, N., Creasey, D. J., Heard, D. E., Lee, J. D., Lewis, A. C., Pilling, M. J., and Zdor, J.: $\mathrm{OH}$ and $\mathrm{HO}_{2}$ chemistry in clean marine air during SOAPEX-2, Atmos. Chem. Phys., 4, 839-856, doi:10.5194/acp-4-839-2004, 2004.

Stevens, P. S., Mather, J. H., Brune, W. H., Eisele, F., Tanner, D., Jefferson, A., Cantrell, C., Shetter, R., Sewall, S., Fried, A., Henry, B., Williams, E., Baumann, K., Goldan, P., and Kuster, W.: $\mathrm{HO}_{2} / \mathrm{OH}$ and $\mathrm{RO}(2) / \mathrm{HO}_{2}$ ratios during the Tropospheric $\mathrm{OH}$ Photochemistry Experiment: Measurement and theory, J. Geophys. Res.-Atmos., 102, 6379-6391, 1997. 
Thornton, J. A., Wooldridge, P. J., Cohen, R. C., Martinez, M., Harder, H., Brune,W. H.,Williams, E. J., Roberts, J. M., Fehsenfeld, F. C., Hall, S. R., Shetter, R. E., Wert, B. P., and Fried, A.: Ozone production rates as a function of NOx abundances and HOx production rates in the Nashville urban plume, J. Geophys.Res., 107, D12, doi:10.1029/2001JD000932, 2002.

Volz-Thomas, A., Lerner, A., Patz, H. W., Schultz, M., McKenna, D. S., Schmitt, R., Madronich, S., and Roth, E. P.: Airborne measurements of the photolysis frequency of $\mathrm{NO}_{2}$, J. Geophys. Res.-Atmos., 101, 18613-18627, 1996.

Volz-Thomas, A., Geiss, H., Hofzumahaus, A., and Becker, K. H.: Introduction to special section: Photochemistry experiment in BERLIOZ, J. Geophys. Res.-Atmos., 108, 8252, doi:10.1029/2001JD002029, 2003

Wernli, H. and Davies, H. C.: A Lagrangian-based analysis of extratropical cyclones. I: The method and some applications, Q. J. Roy. Meteorol. Soc., 123, 467-489, 1997.
Williams, J., Custer, T., Riede, H., Sander, R., Jöckel, P., Hoor,P., Pozzer, A., Wong-Zehnpfennig, S., Hosaynali Beygi, Z., Fischer, H., Gros, V., Colomb, A., Bonsang, B., Yassaa, N., Peeken, I., Atlas, E. L., Waluda, C. M., van Aardenne, J. A., and Lelieveld, $\mathrm{J}$.: Assessing the effect of marine isoprene and ship emissions on ozone, using modelling and measurements from the South Atlantic Ocean, Environ. Chem., 7, 171-182, 2010.

Yang, J., Honrath, R. E., Peterson, M. C., Parrish, D. D., and Warshawsky, M.: Photostationary state deviation-estimated peroxy radicals and their implications for $\mathrm{HO}_{\mathrm{x}}$ and ozone photochemistry at a remote northern Atlantic coastal site, J. Geophys. Res. Atmos., 109, D02312, doi:10.1029/2003JD003983, 2004.

Zorn, S. R., Drewnick, F., Schott, M., Hoffmann, T., and Borrmann, S.: Characterization of the South Atlantic marine boundary layer aerosol using an aerodyne aerosol mass spectrometer, Atmos. Chem. Phys., 8, 4711-4728, doi:10.5194/acp-8-47112008, 2008. 